\title{
STŘEDOVĚKÉ A NOVOVĚKÉ ARTEFAKTY Z NÁDVOŘÍ MĚSTSKÉ RADNICE V ČESKÝCH BUDĚJOVICÍCH A JEJICH SOCIÁLNĚ-EKONOMICKÁ VÝPOVĚD̆
}

\author{
LADISLAV ČAPEK - MICHAL PREUSZ - JIŘÍ MILITKÝ
}

\begin{abstract}
Abstrakt: Při archeologickém výzkumu na nádvoři městské radnice v letech 1996-1997 byly odkryty části tři až čtyr̆ původních městských parcel s hospodářským a provozním zázemím městských domů, které předcházely výstavbě renesanční městské radnice v polovině 16. století. Z archeologického výzkumu bylo ziskáno velké množstvi artefaktů, které byly předmětem studia středověké a novověké materiální kultury. Předkládaný rozbor se věnuje artefaktům materiálově rozděleným na středověkou a novověkou užitkovou (kuchyňskou, stolni a zásobni) keramiku, novověké keramické dýmky, kamnářskou keramiku, předméty ze skla, železa, barevných kovi̊ a na mince. Soubor artefaktů je první ucelenou sondou do sociálně-ekonomického života městských domácností v průběhu středověku a novověku v Českých Budějovicích.
\end{abstract}

Klíčová slova: městská radnice - středověk - novověk - hmotná kultura-České Budějovice.

Medieval and Modern-Age Artefacts from the Courtyard of the Town Hall in České Budějovice and Their Socio-Economic Context

Abstract: Archaeological research in the town hall courtyard conducted in 1996-1997 disclosed parts of three or four urban plots with the economic hinterland of burgher houses that preceded a renaissance town hall built in the mid-16th century. The research yielded a large number of artefacts that were studied as examples of medieval and modern-age material culture. The paper focuses on artefacts divided, in terms of material, into medieval and modern-age utility ceramics (kitchenware, tableware and storage vessels), modern-age ceramic tobacco pipes, stove tiles ceramics, objects of glass, iron and non-ferrous metals, and coins. The series of artefacts provides the first comprehensive insight into the socio-economic life of urban households in České Budějovice in the Middle Ages and the modern age.

Key words: town hall-Middle Ages - modern age-material culture-České Budějovice.

\section{Úvod}

Během archeologického výzkumu na nádvoří městské radnice v Českých Budějovicích v letech 1996-1997 bylo získáno velké množství středověkých a novověkých artefaktů pocházejících ze tří až čtyř původně samostatných městských domů, které předcházely výstavbě renesanční městské radnice v polovině 16. století. Zpracování artefaktů se připravuje do knižní publikace, která bude věnována komplexnímu vyhodnocení tohoto plošně největšího archeologického výzkumu, který byl v historickém jádru města realizován, včetně zpřístupnění veškerého nálezového fondu.

Cílem studie je představení základního typologického a morfologického rozboru artefaktů zahrnujících středověkou a novověkou užitkovou (kuchyňskou a stolní) a kamnářskou keramiku, novověké dýmky, dále sklo a předměty ze železa a barevných kovů. Získané soubory artefaktů jsou důležitým pramenem pro studium provozního vybavení a životního standardu městských domácností a hospodářského zázemí parcel v průběhu druhé poloviny 13. do poloviny 16. století. $\mathrm{S}$ ohledem na majetkové poměry a vyšší ceny nemovitostí na nádvoří městské radnice je studie zaměřena i na možnosti výpovědi materiální kultury o sociálním a ekonomickém postavení (statusu) obyvatel městských domů.

\section{Archeologický výzkum na nádvoří městské radnice}

Plošný předstihový archeologický výzkum na nádvoří českobudějovické městské radnice byl realizován v souvislosti s plánovanou zástavbou radničního dvora. Výzkum provádělo Jihočeské muzeum v Českých Budějovicích pod vedením J. Militkého (2001). Byla použita metoda exkavace pomocí čtvercové či obdélné sítě - bylo položeno celkem 24 sond, mezi nimiž byly ponechány 
kontrolní bloky, které byly následně po dokumentaci půdorysů a řezů sond a dosažení podloží rozebírány. Tímto způsobem byla plošně odkryta podstatná část nezastavěného areálu nádvoří (obr. 1).

Plošný archeologický výzkum se dotkl třri až čtyř původních středověkých parcel městských domů (dnes sloučeny v čp. 1 a 2), zejména v částech jejich dvorních traktů, které předcházely vlastní výstavbě městské radnice v polovině 16 . století. Z nejstarších archeologických situací na městských parcelách datovaných do lokační fáze města po roce 1265 byly odkryty doklady stavebních aktivit, a to v podobě půdorysů zahloubených staveb, tzv. suterénů (jeden celý suterén obj. $4 / 2$ a dva částečně dochované suterény obj. 1/12 a obj. 5/16), a dále řada odpadních jam bez vnitřní konstrukce. Pro nejstarší lokační osídlení bylo typické až čtyřiceticentimetrové souvrství uloženin na ploše dvora i s podílem organického odpadu. Nejstarší sídlištní vrstvy nasedaly na charakteristický probarvený půdní typ, místy dosahující mocnosti až 20 centimetrů. Teprve ke konci 13. století byl areál dvora místy zpevňován valounovou dlažbou a spontánní nárůst vrstev byl tak zastaven. V průběhu 14. století již výrazné sídlištní stratigrafie na ploše dvora postupně mizí, spáleništní vrstvy dokládají likvidaci lehčích dřevěných staveb na parcelách. Na přelomu 13. a 14. století byla založena kamenná parcelní zed’, která rozdělovala hloubkově dvě původně samostatné parcely domu čp. 1 (označené jako parcely A a B). Ve stejném období vznikla i kamenem roubená studna obj. 2/2 čtvercového půdorysu. Na počátku 14. století (nejvýše v 1. polovině) byl založen nejstarší zděný trakt městského domu na parcele B (obr. 2 a 3).

Období 14.-15. století reprezentovaly dva obdélné cihlové objekty (obj. 1/4 a 1/10) vložené do zadní části gotického traktu domu, které pravděpodobně byly součástí sladovny (nádrž na vodu a dvouprostorové otopné zařízení). Do tohoto období lze zařadit také menší hospodářské objekty (komory?) a dvojici kruhových, kamenem roubených studní (obj. 1/21 a obj. 1/23), které byly společně se starší studnou (obj. 2/2) ve druhé polovině 15 . století sekundárně využívány jako odpadní jímky k ukládání domového odpadu. Do 15. století lze datovat rovněž zděný objekt obdélné jímky (obj. 1/20), která podle archeobotanické analýzy její výplně sloužila i jako latrína (Jankovská a kol. 2002, 822). V 15. století byl vystavěn severní gotický trakt a na parcele B tak vznikl hotový městský dům se středovým průjezdem a dvěma postranními bočními trakty (obr. 2 a 3). Především z objektů studní, latríny a cihlových objektů pochází nejpočetnější soubory artefaktů - keramiky, skla, artefaktů ze železa a barevných kovů a předmětů z organických materiálů (dřeva a kůží), datované do doby kolem poloviny 15. století.
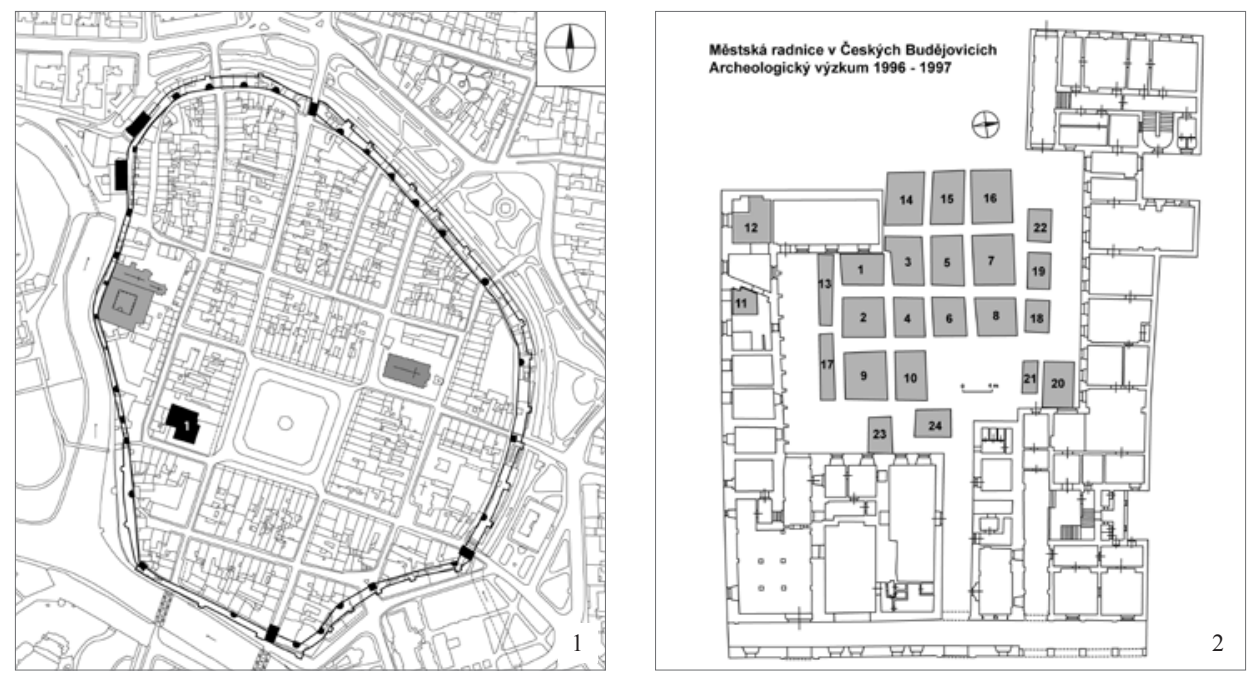

Obr. 1. České Budějovice, městská radnice. 1 - poloha radnice na plánu města, 2 - půdorys nádvoří městské radnice s vyznačenými sondami archeologického výzkumu. Na základě terénní dokumentace vytvořil L. Čapek.

Abb. 1. České Budějovice, städtisches Rathaus. 1 - Lage des städtischen Rathauses auf dem Stadtplan, 2 - Grundriss des Rathaushofes mit eingezeichneten Sondierschnitten der archäologischen Grabung. Anhand der Geländedokumentation erstellt von L. Čapek. 

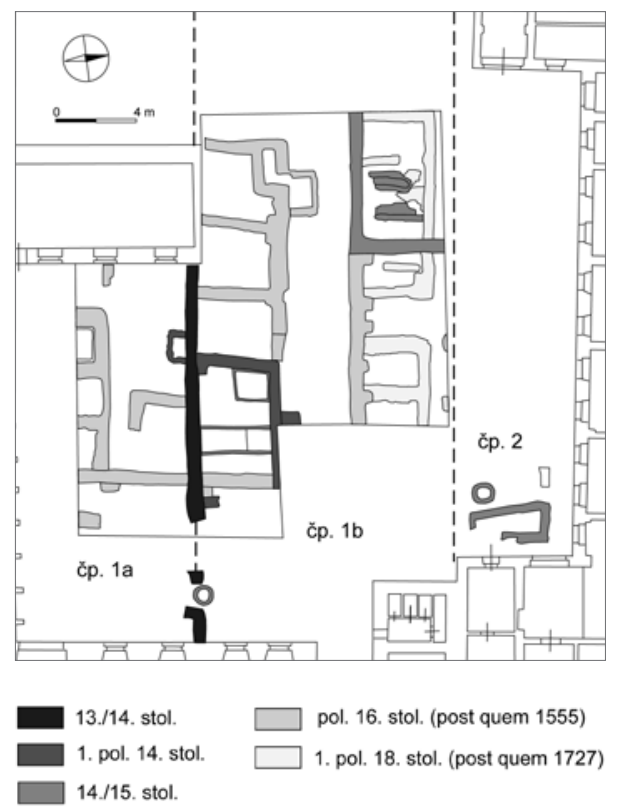

pol. 16. stol. (post quem 1555)

1. pol. 18. stol. (post quem 1727)

Obr. 2. České Budějovice, nádvoří městské radnice. Půdorysy odkrytých konstrukcí a jejich stavební vývoj. Vyznačena parcelní zed' mezi čp. 1a (parcela A), čp. 1 b (parcela B) a čp. 2 a půdorys gotického traktu domu $z$ 1. poloviny 14. století. Na základě terénní dokumentace vytvořil L. Čapek.

Abb. 2. České Budějovice, Hof des städtischen Rathauses. Grundriss der freigelegten Baukonstruktionen und ihre bauliche Entwicklung. Kenntlich gemachte Parzellenmauer zwischen Konskriptionsnr. 1a (Parzelle A), Konskriptionsnr. 1b (Parzelle B) und Konskriptionsnr. 2 und und Grundriss des gotischen Haustraktes aus der ersten Hälfte des 14. Jhdts. Anhand der Geländedokumentation erstellt von L. Čapek.

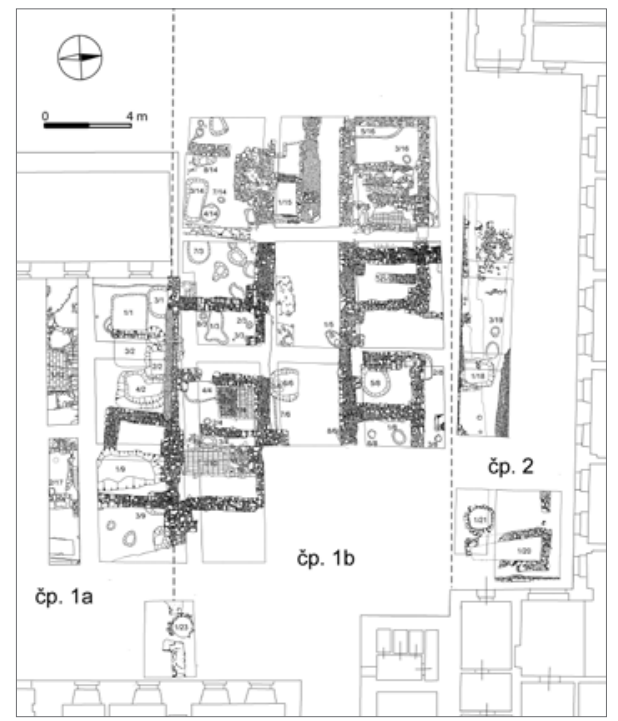

Přelom 15. a 16. století pak charakterizují především stavební úpravy dvorních traktů spojené $\mathrm{s}$ výstavbou městské radnice $\mathrm{v}$ polovině 16. století, kdy vzniklo renesanční křídlo městské radnice a došlo ke stavebnímu propojení domů na parcelách A a B souvisejícímu $\mathrm{s}$ úpravami interiérů pro potřeby radničního domu. Sousední dům čp. 2 zůstal nadále samostatný a byl připojen $\mathrm{k}$ areálu městské radnice až na př̀lomu 18. a 19. století (obr. 2 a 3).

\section{Historie městských domů $v$ čp. 1 a počát- ky renesanční městské radnice}

Na nádvoří městské radnice (dnes čp. 1) se nacházely původně dva městské domy. Ten na parcele A vlastnil od 80 . let 14 . století měšt’an Mužík. V berní knize města je ohodnocen na 20-30 hřiven - patřil k nejdražším ve městě. Jeho majitel navíc platil z obchodu se solí a později i z masného krámu a bliže neurčeného řemesla. V roce 1407 dům získal Ondřej Knoll, jenž přiznával dokonce vyšší cenu 30-40 hřiven a platil také z masného krámu, obchodu se solí a blíže neurčeného řemesla. Ondřej Knoll zasedal v letech 1405-1418 v městské radě. V rozmezí let 1418-1433 byla do tohoto domu městskou obcí přemístěna radnice (Borská-Urbánková 1965, 116; MukVlček-Urban 1988, 4). V roce 1482 je v knize městské sbírky (tzv. knihy lozunků) označen Knollův dům jako praetorium o hodnotě 20 hřiven (Liber losungarum ab ao 1482, f. 10).

$\mathrm{Na}$ sousední parcele $\mathrm{B}$ stál dům, který vlastnil v roce 1380 Kristián Phnestl, jenž $z$ domu platil 18 hřiven. Poté se dům dostal do dědičného držení rychtářské rodiny Klariců, náležící $\mathrm{k}$ nejbohatším rodinám ve městě. Počátkem 15. století platil rychtár̆ Klaric z majetku v odhadní ceně 80 hřiven, do které však byl započítán i předměstský dvůr o hodnotě 50 hřiven, dále masný krám, obchod s dobytkem a se solí. Posledním zmiňovaným soukromým vlastníkem domu byl Václav Terczebuch, který platil z domu 18 hřiven (Borská-Urbánková 1965, 116; Muk-Vlček-Urban 1988, 4).

Obr. 3. České Budějovice, nádvoří městské radnice. Půdorysy odkrytých situací. Číslem označeny všechny středověké a novověké objekty. Na základě terénní dokumentace vytvořil L. Čapek.

Abb. 3. České Budějovice, Hof des städtischen Rathauses. Grundrisse der freigelegten Situationen. Alle mittelalterlichen und neuzeitlichen Objekte wurden mit Nummern bezeichnet. Anhand der Geländedokumentation erstellt von L. Čapek. 
V roce 1494 byl dům vykoupen se svolením krále Vladislava Jagellonského městskou obcí a připojen k radnici, jež vyplatila vdově Dorotě dvě splátky o celkové výši 80 a 49 kop českých grošů (Huyer 1920, 3, č. 84).

Základem pro výstavbu nové městské radnice se staly oba domy - Knollův a Terczebuchovský -, které ještě v roce 1514 nebyly stavebně propojeny. Kniha lozunků uvádí v roce 1515 Knollův dům jako radnici - „praetorium“, zatímco Terczebuchovský dům je uveden jako „domus communitatis" (Liber losunguram ab ao 1514, 9v.-10).

Oba domy byly pro potřeby městské radnice v první polovině 16 . století stavebně upravovány. V Knollově domě došlo k obnově zdí, úpravě zasedací světnice a dalším kamenickým pracím (Huyer 1920, 3, č. 84). V roce 1505 se v radničním domě šenkovalo víno (Mareš 1920, 12) a v roce 1529 bylo zřízeno v přízemí vězení, a také byt radničního sluhy (Huyer 1920, 3, č. 84). Stavební úpravy Terczebuchovského domu se týkaly především př́izemních prostor, kde byla zřízena v roce 1531 vážnice, nová světnice $v$ patře a tzv. pokoj královny, v témže roce je v něm krátce zaznamenán krátkodobý pobyt Anny Jagellonské, manželky Ferdinanda I. (Muk-Vlček-Urban 1988, 5-6).

Až do poloviny 16. století tyto domy existovaly jako dvě samostatné jednotky. Výstavba renesanční radnice probíhala v letech 1555-1558 za primátora Quirina. Oba radniční domy byly strženy a na jejich místě byla postavena novostavba, která do jisté míry zachovala původní dispozici. $\mathrm{Z}$ předchozích staveb zůstala zachována pouze př́zemní sladovna a vězení s bytem radničního sluhy. V roce 1548 bylo zbudováno postranní křídlo s kancelářskými a zbrojními komorami a nová vážnice v Terczebuchovském domě. V roce 1543 byla zrrízena solní komora a nové sklepy, které byly podle potřeby využívány jako pokladnice nebo jako prachárna (Muk-Vlček-Urban 1988, 6-7).

V roce 1555 došlo k částečnému ubourání zdí radničních domů a $\mathrm{k}$ nim byly přizděny pilíře, na které byla svedena klenba. Nově vznikla nárožní mohutná věž opatřená hodinami a zakončená bání. V roce 1556 došlo k zaklenutí horního patra, k osazení dřevěného krovu a posléze k výmalbě interiérů (Huyer 1920, 3, č. 84). Další zásahy do radničních budov se omezily zřejmě jen na drobnější přestavby a na nové úpravy interiérů, středověký ráz dispozice přízemí však nenarušily. V souvislosti s výstavbou vzniklo dvorní, částečně zbořené kř́ídlo na místě Knollova domu. Stavitelem renesanční radnice byl italský mistr Honz Vlach pravděpodobně totožný s Hansem Spatzem (Huyer 1920, č. 85; Muk-Vlček-Urban 1988, 79).

Podoba radnice $z$ doby kolem roku 1555 představuje pokročilejší fázi nejranější renesance (Líbal-Muk 1969, 65; Kibic 1988, 52). Dochovala se na Willenbergově vedutě města z roku 1602 a na rytině Petra Wussina z roku 1654. Renesanční městskou radnici lze charakterizovat jako jednopatrovou stavbu otevřenou do přízemí arkádami s podloubím, s obloučkovitými štíty a s nárožím doplněnou o hranolovou věž s hodinami krytou masivní renesanční bání. Fasáda radnice byla zdobena sgrafity.

\section{Artefakty z nádvoří městské radnice}

Z plošně rozsáhlého archeologického výzkumu nádvoří městské radnice bylo získáno velké množství artefaktů, které tvoří komplexní součást tzv. materiální kultury vrcholného až pozdního středověku a raného novověku. Archeologické nálezy byly po skončení výzkumu laboratorně ošetřeny, byla provedena jejich základní evidence a dnes jsou uloženy ve sbírkách Jihočeského muzea v Českých Budějovicích.

\subsection{Metoda zpracování a vyhodnocení}

Metoda analýzy a zpracování středověkých a novověkých artefaktů z nádvoří městské radnice vycházela $\mathrm{z}$ deskripce formálních vlastností a podrobného typologicko-morfologického rozboru, podle již zavedených schémat tř́́dění, deskripce a popisu jednotlivých artefaktů; podle materiálu rozdělených na keramiku, sklo, železo a barevný kov včetně mincí. Stranou hodnocení a publikačního představení na tomto místě prozatím zůstaly předměty ze dřeva a kủže a jiných organických materiálů. 
Zpracování a vyhodnocení středověké keramiky vycházelo z disertační práce L. Čapka (2013, s další literaturou) a u novověké keramiky včetně dýmek z prací M. Preusze $(2015 ; 2015 \mathrm{a}$, s další literaturou). Morfologie kamnářské keramiky navazovala na práci Z. Smetánky (1969, 228-262), s prrihlédnutím k dalším pracím vzhledem k převaze nádobkových kachlů nad kachli komorovými (např. Hazlbauer-Richter 1990, 416-434; Krajíc 1997; Orna 2005; Tetour 2014). Typologie středověkých skel vycházela z řady publikovaných studií F. Frýdy, E. Černé a H. Sedláčkové (např. Frýda 1990, 59-84; Černá a kol. 1994; Sedláčková 2003, 127-138).

Třídění předmětů ze železa bylo převzato podle zpracovaného a publikovaného souboru železných předmětů ze Sezimova Ústí (Krajíc 2003), s přihlédnutím k některým souborům železných předmětů z vesnického prostředí (nap̌r. Belcredi 1989, 437-472; 2006, 345-378). Největší problémy byly spojeny $\mathrm{s}$ tř́iěním, určováním a typologickým zařazením předmětů z barevných kovů, nebot' u nás dosud chybí souhrnné studie a přehledy zpracovaných nálezových souborů z městského prostředí (srov. Procházka 1990); analogie k některým drobným kovovým předmětům byly zjištěny v zahraniční, zejména německé literatuře (Krabath 2001; Lungerhausen 2004; Harder 2010).

Při vyhodnocení jednotlivých skupin a typů artefaktů byl kladen důraz na jejich prostorovou distribuci, která byla specifikována na kontext s referenčními jednotkami (sonda - sektor objekt/sektor - kontext) v horizontální stratigrafii a ve vertikální stratigrafii (sonda - objekt - stratum - kontext). Ke studiu prostorové distribuce byly využity analytické nástroje v geografických informačních systémech (dále jako intra-site GIS) ${ }^{1}$ a programy na tvorbu stratigrafických diagramů. ${ }^{2}$

\subsubsection{Kuchyňská a stolni keramika}

Nejpočetnější soubory artefaktů tvořila středověká a raně novověká keramika. Celkem bylo zpracováno přes 24 tisíc keramických jedinců a 163 celých nebo rekonstruovaných tvarů, jež pocházely převážně z výplní studní obj. 2/2, 1/21 a 1/23 a z výplně odpadní jímky obj. 1/20. Při analýze kuchyňské, stolní a zásobní keramiky byl kladen důraz na deskripci typologických, morfologických a technologických kvalit (podrobně rozvedeno v Čapek 2013, 153-155).

Určení typů a druhů nádob vycházelo z typologických znaků keramiky - charakteristických okrajů, výdutí, den, funkčních aplikací, výzdoby, a také podle profilace tvaru nádob u celých nebo rekonstruovaných tvarů nádob. Deskripce morfologických znaků - okrajů - vycházela z přijatého členění okrajů do základních skupin, typů a variant definovaných pro vrcholně středověké až raně novověké období (srov. Vařeka 1998, 125-126), dále byl vytvořeny skupiny a typy pro další morfologické a funkční části nádob - dna, ucha, držadla apod. Podobně byla rovněž rozdělena do skupin, typů a variant i výzdoba na keramice. Technologické vlastnosti byly sledovány prostřednictvím makroskopické deskripce keramických tříd, která zahrnovala strukturu a složení keramické hmoty, výpal, úpravu povrchu a barvu (srov. Procházka-Peška 2007, 241-245; Nováček-Tetour 2003). Některé vůdčí keramické třídy byly podrobeny optické mikroskopii, rentgeno-flourescenční spektrometrii - XRF a rentgenové difrakční analýze - RTG (Čapek-Čekalová- ̌́íha 2014, 525-542).

Deskripce okrajů a keramických tříd se stala prostředkem $\mathrm{k}$ řešení chronologického modelu vývoje vrcholně až raně novověké keramiky z nádvoří městské radnice. Na základě vzájemné interakce mezi okraji, keramickými třídami a stratigrafickými jednotkami byly prostřednictvím statistických metod korespondenční analýzy vyčleněny základní chronologické horizonty (podrobně rozvedeny v práci Čapek 2013, 246-252). Cílem zde není detailní popis jednotlivých chronologických horizontů a jejich keramické náplně, které budou publikovány na jiném místě, ale především souhrnná prezentace keramiky v rámci širších časových intervalů rozdělených na keramiku druhé poloviny 13. století, keramiku 14.-15. století a raně novověkou keramiku přelomu 15. a 16. století, které se odráží ve změně v keramické produkci. Základní schéma vývoje keramických tvarů ukazuje vývojový sekvenční diagram (obr. 4).

1 Příklad prostorové distribuce středověké a raně novověké keramiky v horizontální stratigrafii s využitím prostorových a analytických nástrojů v programu ArcMap 10 je ukázán ve studii L. Čapka (2015).

$2 \mathrm{~K}$ tvorbě stratigrafických diagramů byl využit program Le Stratifiant 0.3 .5 , jehož tvůrcem je B. Desachy (2004). 
17./18. stol.

16./17. stol.

15./16. stol.
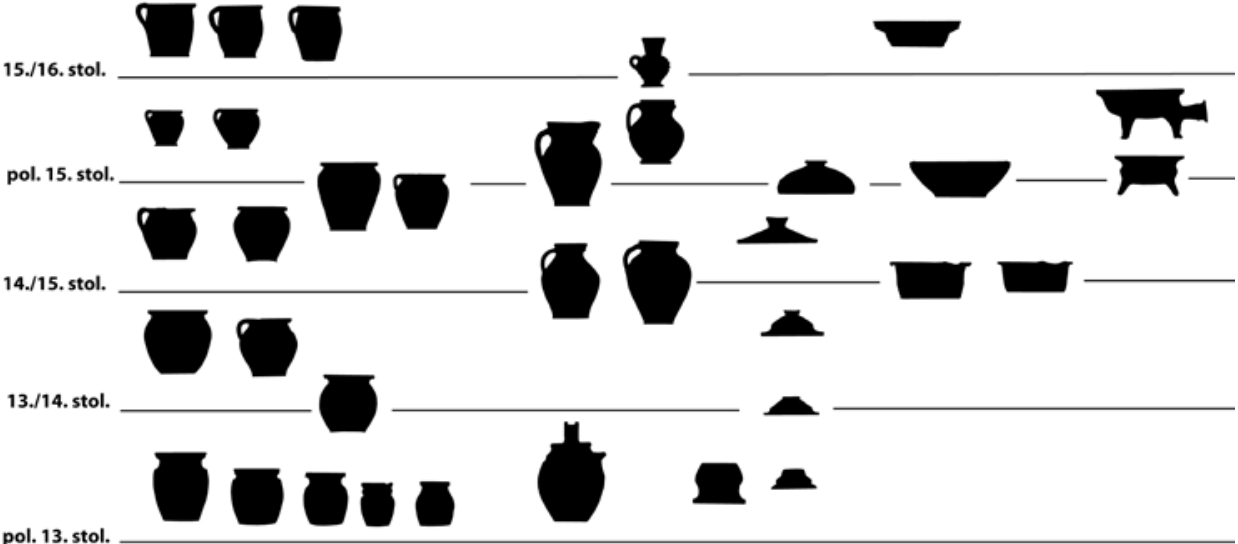

pol. 13. stol.
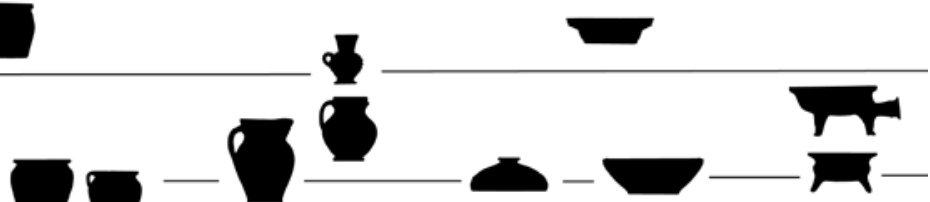

Obr. 4. České Budějovice, nádvoří městské radnice. Vývojový diagram keramických tvarů 2. poloviny 13. až 17./18. století. Vytvořil L. Čapek.

Abb. 4. Ceské Budějovice, Hof des städtischen Rathauses. Entwicklungsdiagramm der Keramikformen für die Zeiträume 2. Hälfte 13. bis 17./18. Jahrhundert. Erstellt von L. Čapek.

\subsubsection{Středověká keramika 2. poloviny 13. až přelomu 13. a 14. století}

Nejstarší českobudějovická keramika z nádvoří městské radnice, ale i z jiných částí města patří ke skupině tzv. grafitové (tuhové) keramiky, která se vyznačuje keramickou surovinou s určitou procentuální příměsí grafitu a která v jižní části jižních Čech má výrazně regionální charakter, v závislosti na dobře dostupných ložiscích grafitu, vycházející ještě ze starších „hradištních“ tradic výroby. Podle příměsi grafitu v keramické hmotě a jeho dalšího třídění na plastický krystalicko-šupinatý až mikrokrystalický grafit lze dobře sledovat - i s ohledem na charakteristické profilace okrajů nádob (hrnců) - vývoj produkce grafitové keramiky od druhé poloviny 13. století do přelomu 13. a 14. století. Užití grafitové keramiky je spojeno především s první a druhou generací obyvatel města.

V nejstarším sídelním horizontu na nádvoří městské radnice po založení města v roce 1265 , ve vrstvách nad půdním typem a ve výplních nejstarších zahloubených objektů s funkcí odpadních jam a zahloubených staveb (suterénů), převažují keramické třídy s plastickým hrubším krystalicko-šupinatým grafitem, který vystupuje na vnějším a vnitřním povrchu tak, že někdy vytváří až kovově ocelový lesk. Výrazná je i příměs slídy v keramické hmotě. Na vnitřním povrchu se místy objevují stopy po nedokonalém obtáčení nádob, či nedokonalém tvarování. Grafitová keramika byla vypalována redukčně až oxidačně-redukčně, o čem svědčí tmavě šedá až šedohnědá barva střepu; vlastní jádro střepu je zpravidla tmavě černé. V poslední třetině 13. století dochází postupně ke zjemňování plastického grafitu v keramické hmotě a objevují se keramické třídy s jemně drceným mikrokrystalickým grafitem. Výpal je zpravidla již oxidační, projevuje se šedo- až okrovohnědým až světle žlutohnědým odstínem a výrazným černým jádrem střepu (tzv. sendvičový efekt). Postupně ke konci 13. století se objevují i třídy s vnější úpravou v podobě vrstvy z jemně plavené hlíny (engoba), a také dokonalejší modelace. Keramické třídy s jemně drceným grafitem vyznívají v souborech na přelomu 13. a 14. století, kdy dochází k razantnímu nástupu redukční keramiky.

Základní tvary nádob z nádvoří městské radnice z poslední třetiny 13. století tvoří bezuché hrnce vejčitého tvaru středních a menších rozměrů, pro které je charakteristické odsazení hrdla a plece v podobě ostrého lomu přibližně v horní třetině výšky nádoby (obr. 5). Ve skladbě okrajů hrnců převažují jednoduše profilované šikmo seříznuté okraje s vlastním okrajem mírně nahoru 


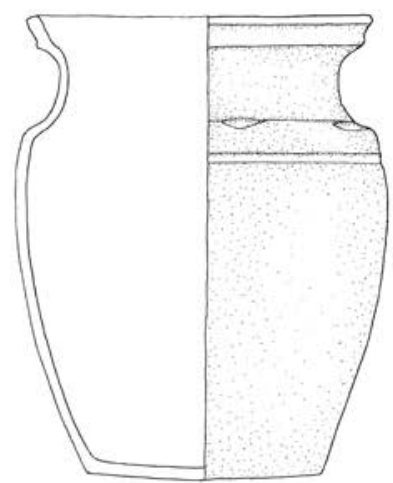

1
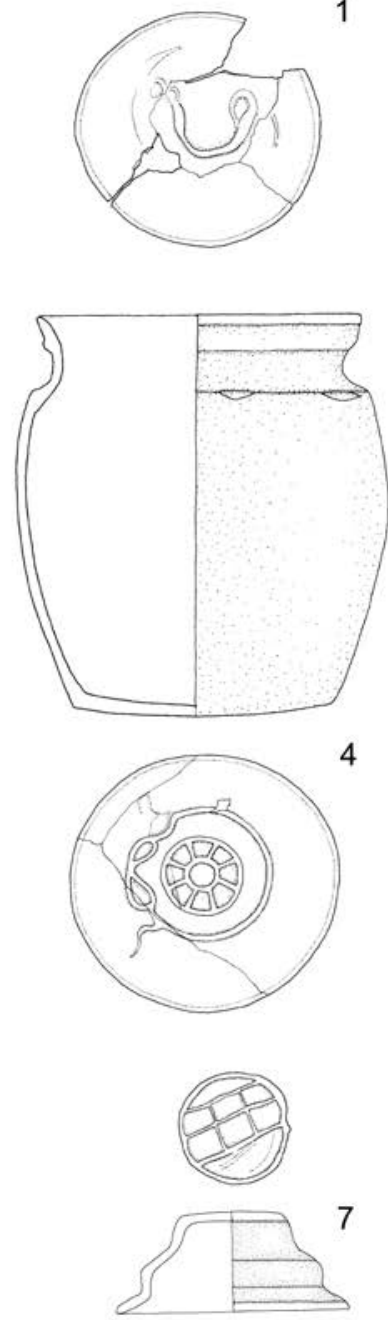

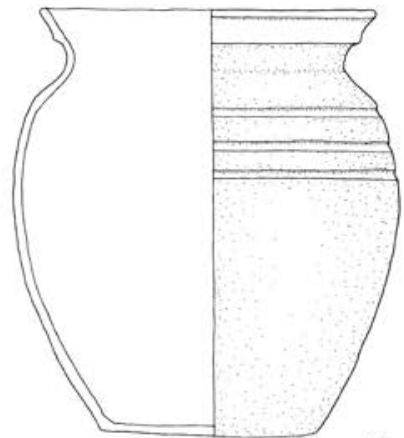

2
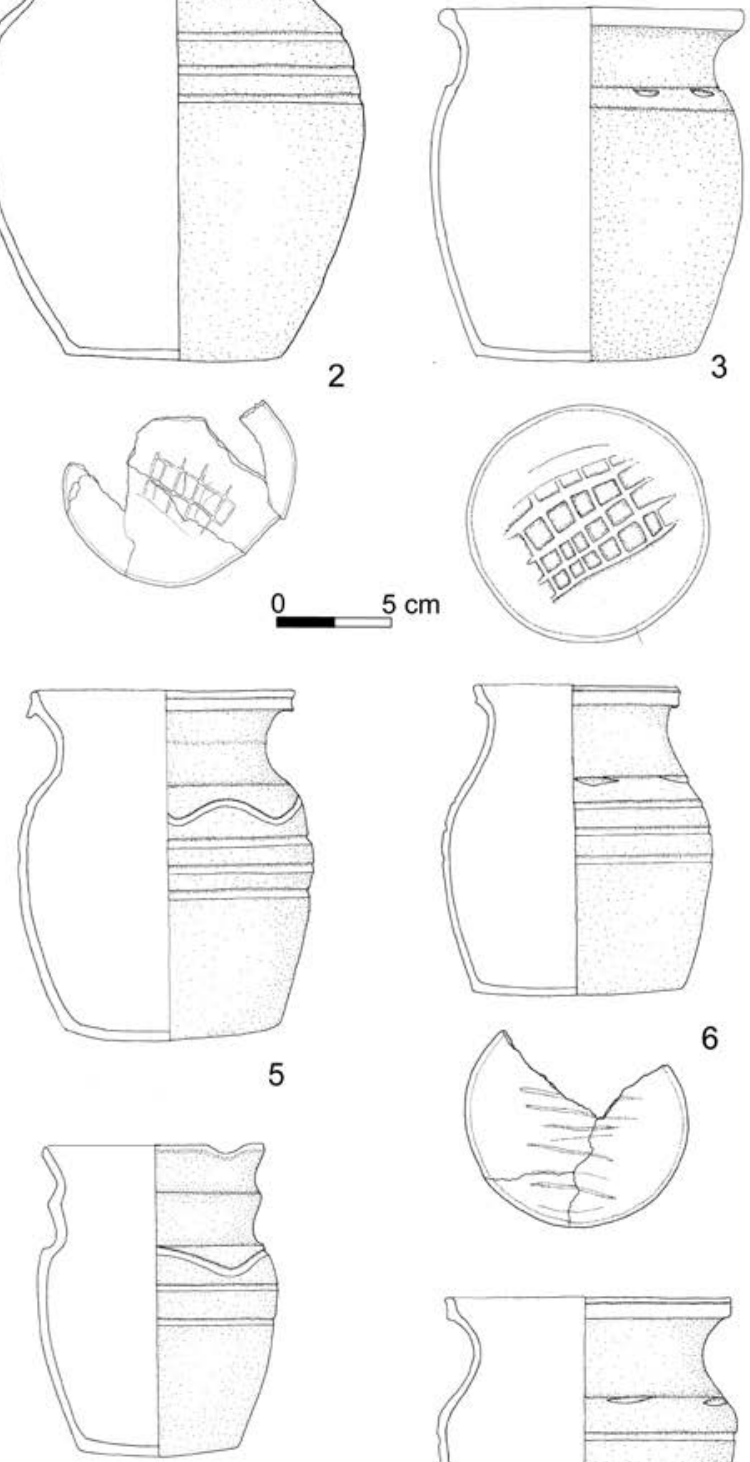

8
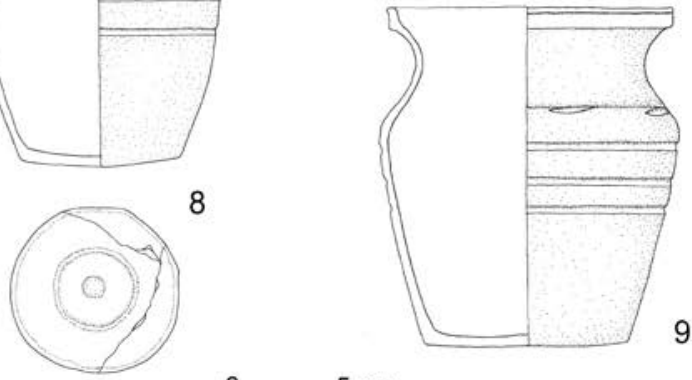

$5 \mathrm{~cm}$

Obr. 5. České Budějovice, nádvoří městské radnice. Grafitová keramika 2. poloviny 13. století. Kresba L. Čapek. Abb. 5. České Budějovice, Hof des städtischen Rathauses. Grafitkeramik der 2. Hälfte des 13. Jhdts. Zeichnung L. Čapek. 
vytaženým, či dolů protaženým, nebo okraje s ústím šikmo vně vyhnutým a vlastním okrajem kyjovitě zesíleným a nahoře prožlabeným, které vycházejí ještě z hradištního vývoje před polovinou 13. století (např. obr. 5:5). Později se objevují okraje vně vyhnuté zesílené s vlastním okrajem zaobleným a zevnitř prožlabeným (např. obr. 5:3), či okraje vzhůru vytažené směrem nahoru se zužující s oblou lištou nebo hranou (např. obr. 5:4). Pro přechodový horizont ke konci 13. století jsou charakteristické tzv. římsovité okraje a okraje nepravých okruží prožlabených jak z vnější, tak i vnitřní strany (např. obr. 5:9). Typickou výzdobou hrnců je jednoduchá či vícenásobná rytá rýha širšího průměru a zejména pak nehtovité či kapkovité vrypy, nejčastěji umístěné na ostrém lomu hrdla a plece (obr. 5:1, 3, 4 a 9). Ojediněle se objevuje jednoduchá rytá vlnice (obr. 5:5 a 8). Později k závěru 13. století již výrazně ubývá nehtovitých a kapkovitých vrypů na úkor ryté šroubovice a nejstarší radélkové výzdoby. Na dnech nádob se mnohdy objevují reliéfní značky nejčastěji v podobě soustředných kruhů nebo tzv. mřŕžovaných značek (obr. 5:2-4; srov. Čapek 2015, 201-225).

Kromě tvarů hrnce se v souboru vyskytují i větší ,zásobni" tvary hrnců a grafitové zásobnice s charakteristickým hraněným kyjovitým nebo mírně zaobleným okrajem lichoběžníkovitého průřezu. $Z$ dalších tvarů jsou pak výrazně zastoupeny zvonovité misky-poklice esovité profilace s velkým knoflíkem, často také opatřeným hrnčířskou značkou (obr. 5:7). Jen naprosto ojediněle byl v souboru rozpoznán tvar džbánu a konvice se třmenovým uchem a trubkovitou výlevkou. Jiné keramické tvary prakticky ve druhé polovině 13. století neznáme. Nejstarší českobudějovická grafitová keramika vykazuje řadu znaků a podobností s grafitovou keramikou z oblasti Českokrumlovska (Ernée-Vařeka-Zavřel 1997, 259-268; Ernée-Vařeka 1998, 217-230), ale i z jiných částí jižních Čech a s určitou návazností na hornorakouskou grafitovou keramickou produkci (Scharrer-Liška 2007).

Ze souborů keramiky z konce 13. století se vymyká několik ojedinělých nálezů malých nádobek (mističek a hrnků) z jemně plavené bělavé hlíny (tzv. bílé zboží), které lze jednoznačně považovat za import. K této skupině náleží i keramický zvonek a okraj džbánu, které nesou stopy červeného malování. Otázka jejich původu není zcela jasná. Obdobné nálezy drobných keramických miniatur z bílé „kř́ídové“ keramiky jsou doloženy v Plzni, přičemž jejich provenience je shledávána v oblasti Saska (Nováček a kol. 2014, 160, obr. 75); známé jsou nálezy malých nádobek z bělavé hlíny i s červeným malováním z Mostu, kde jsou datovány již do 13. století až kolem poloviny 14. století (Klápště ed. 2002, 21). V literatuře, zvláště v historických pracích, se někdy objevuje názor, že tato bílá červeně malovaná keramika je dokladem německé komunity ve městě (Kovář 2015, 115), ovšem neznáme cestu, kterou se tato keramika mohla dostat do nálezového kontextu.

\subsubsection{Středověká keramika 14.-15. století}

Počátek 14. století je charakteristický nástupem redukční keramiky, která vytlačila tradiční domácí produkci grafitové keramiky. Na základě rozboru keramiky přelomu 13. a 14. století se ukazuje, že tato změna $\mathrm{v}$ keramické produkci nebyla náhlá - ještě v průběhu první poloviny 14. století se lze ojediněle setkat s keramikou s jemnou grafitovou substancí v keramické hmotě. Na přelomu 13. a 14. století se objevují nejstarší redukční třídy, které se vyznačují výraznou příměsí zrn hornin a písku a také nekvalitním redukčním výpalem, projevujícím se na keramice prasklinami na vnějším povrchu. Postupně však v průběhu 14. století docházelo k jeho zkvalitňování a objevují se tenkostěnné černošedé a později charakteristické modrošedé třídy dokonale redukčního výpalu, již bez výrazných příměsí v keramické hmotě. Dlouho se však ještě v průběhu 14. a do počátku 15. století udržovala výroba keramiky na pomalu rotujícím kruhu, o čem svědčí stopy po podsýpání den. Teprve až v 15. století postupně převládla technologie výroby keramiky na rychle rotujícím kruhu s dokonalými stopami po vytáčení.

Pro sledování vývoje tvarů nádob ve 14. století chybí dostatečně reprezentativní soubory, nebot' došlo k proměně způsobu zacházení s keramickým odpadem, a tak většinu keramických tvarů z nádvoří městské radnice známe až ze sekundárních výplní zahloubených objektů z druhé poloviny 15 . století, které ztratily svoji primární funkci - cihlové objekty, studny a odpadní jímka. 
Na základě rozboru keramiky 14. století lze usuzovat, že základním tvarem zůstal hrnec středních a menších rozměrů s kulovitým a později vejčitým tělem (obr. 6). Typickými okraji hrnců ve 14. století jsou okraje pravých a nepravých okruží (např. obr. 6:3), dále se objevují vodorovně vyložené okraje a okraje tzv. střechovité. Výzdobu tvoří především rytá šroubovice a pro počátek 14. století je charakteristický nástup jednoduchých geometrických radélek. Pro pokročilé 14 . století a počátek 15 . století je typická větší tvarová variabilita hrnců s uchem různých

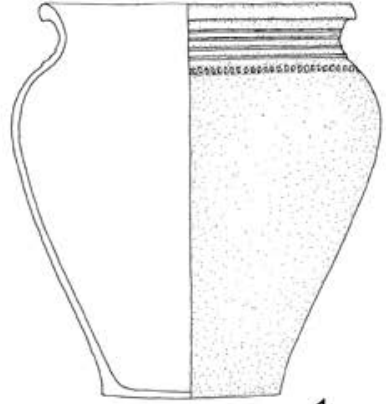

1

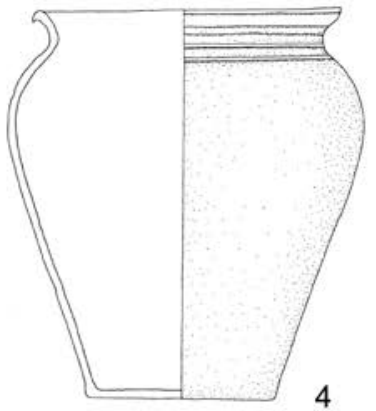

4
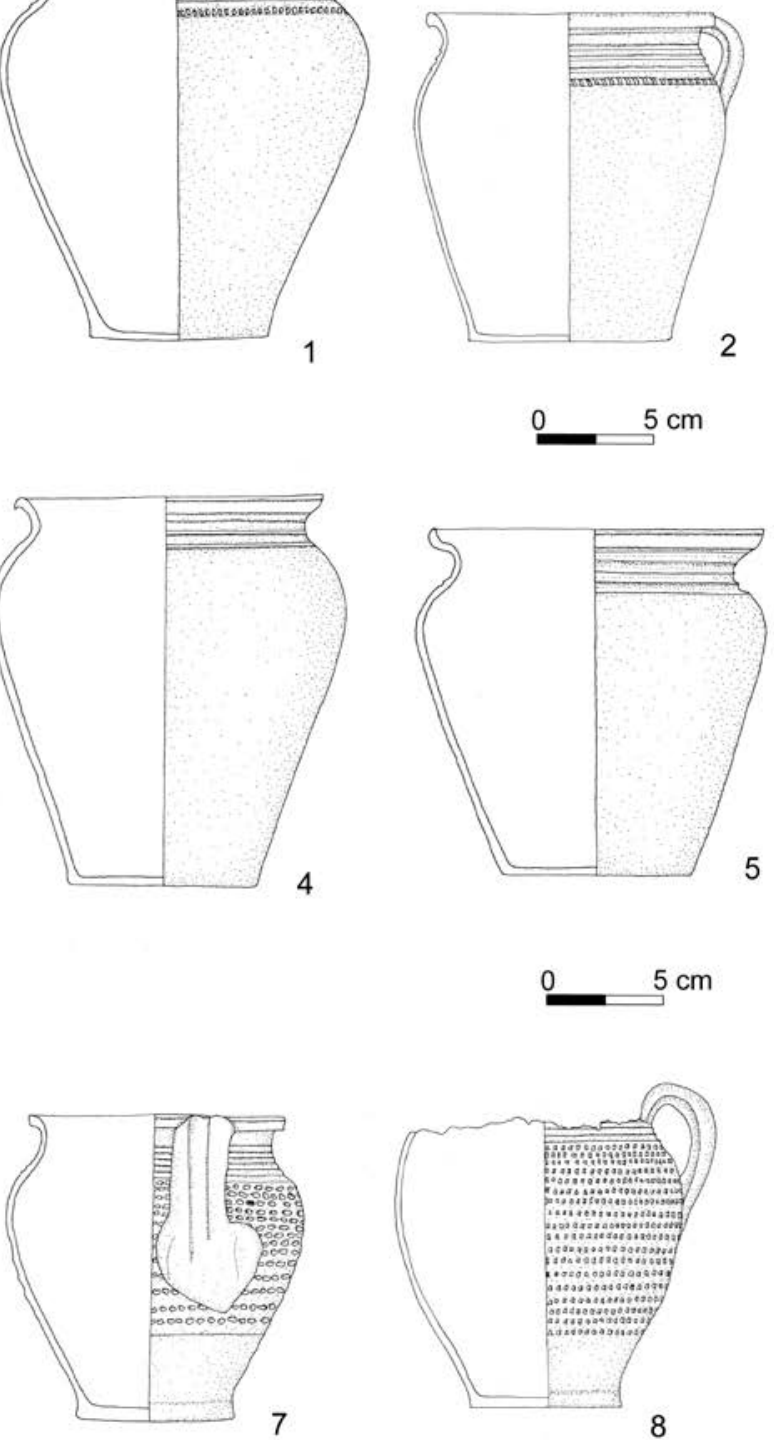

8
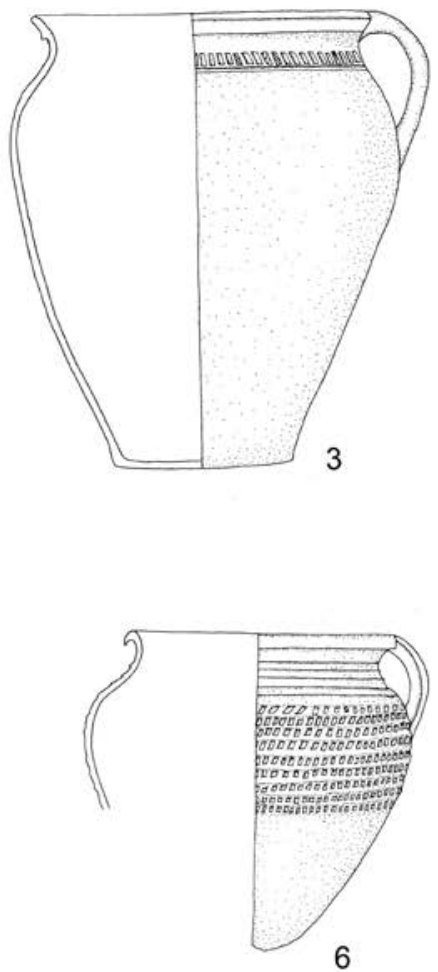

6

Obr. 6. České Budějovice, nádvoří městské radnice. Redukční keramika poloviny 15. století ze středověkých studní. Kresba L. Čapek.

Abb. 6. České Budějovice, Hof des städtischen Rathauses. Reduktionskeramik aus der Zeit Mitte 15. Jhdt. aus mittelalterlichen Brunnen. Zeichnung L. Čapek. 
velikostních a objemových rozměrů s charakteristickými ovalenými okraji, pro průběh 15 . století především s okraji přehnutými (obr. 6:1-2, 4 a 6). V 15. století nabývá radélková výzdoba složitějších kombinovaných geometrických motivů pokrývajících i ve více pásech horní třetinu těla nádob často $v$ kombinaci se stupňovitou nebo vývalkovou šroubovicí na podhrdlí (obr. 6:6-8).

Zatímco ve 14. století je zastoupení džbánů ještě ojedinělé, v 15. století se již v souborech výrazněji projevují. Pro džbány s kulovitým a vejčitým tělem a užším hrdlem jsou typické okraje vyšších žlabených okruží s lištou, připojených pomocí páskového ucha k tělu džbánů. Překvapivě málo je doloženo nálezů pohárů, a to pouze ve zlomcích. $Z$ dalších keramických tvarů se objevují zvonovité poklice s jednoduchým knoflíkem, a také různé tvary mís, misek a kahanů. Pro 14. a zřejmě i velkou část 15 . století jsou typické tuhové zásobnice s neplastickým grafitem, vnější úpravou pomocí engoby a s charakteristickými kyjovitými okraji. Zcela novým tvarem v závěru 15. století jsou trojnohé pánve. Pro soubory 15. století s převahou redukční keramiky lze v oblasti jižních Čech nalézt analogie zejména z měst Tábora, Sezimova Ústí (Richter-Krajíc 2001, 157-158) a Soběslavi (Krajíc 1990, 97-120).

Do skupiny keramiky 14.-15. století lze datovat i dva nálezy keramických plastik, a to figurek koníčků (např. Měchurová 2009, 173-189). Celá figurka světle hnědého glazovaného koníčka se sedlem se našla ve vrstvě ve výplni studny č. $2 / 2$; dále byl objeven fragment figurky koníčka (zachovalá je pouze jeho přední část) vyrobené ze světlé jemně plavené keramické hlíny potažené červenohnědou engobou. Do zmíněného období spadá i nález části zvláštní antropomorfní akvamanile vyrobené z redukční keramiky.

\subsubsection{Pozdně středověká až novověká keramika}

Keramické soubory z horizontu pozdního středověku a raného novověku na nádvoří městské radnice pocházejí především ze zásypových vrstev a navážek, které jsou spojené s výstavbou městské radnice v polovině 16 . století a s výstavbou renesančního traktu.

Na konci 15. století se již v určitém procentu objevují raně novověké polévané keramické třídy světlého střepu s olovnatými transparentními glazurami nejčastěji v barvě žluté, zelené nebo červenohnědé. Vnitřní glazury jsou často přetaženy přes okraj a ucho. Stále však převažuje keramika tvrdého redukčního výpalu a v některých př́ípadech i s ocelově lesklým (,leštěným“") povrchem, za kterým lze snad hledat snahu o imitaci cínového nádobí. V mladším novověkém období se setkáváme i se zakuřovanou keramikou, jejíž povrch místy zdobí vleštování. Tato keramika bývá považována za pokračování vývoje předchozí redukční pálené produkce (Pajer 1983, 75). Z importů byly nalezeny zlomky loštických pohárů. Z tohoto období pochází i zlomky světle až tmavě hnědých kamenin (waldenburská kamenina?) se solenou glazurou a vzácně se vyskytuje i kamenina typu Westerwald (např. Heege 2009).

Z keramických tvarů se objevují hrnce s uchem, nejčastěji soudkovitého tvaru, různých velikostních kategorií, dále džbány, a také velké spektrum hlubších mís. Objevují se i trojnohé pánve s vnitřními glazurami. Nálezy talír̆ů jsou ještě zcela ojedinělé, více je nálezů tzv. hlubších talířovitých mís. Vzácný je nález malého džbánku s kulovitým tělem a trychtýřovitým hrdlem a malým ouškem s netransparentní světle zelenou vnější i vnitřní glazurou (obr. 7:1). Tělo džbánku a ouško je zdobeno plastickou výzdobou hustě umístěných květů růží. $Z$ dalších tvarů je to pak nález hlubší mísy z cihlově červené hrnčiny s talířovitým podokrajím a podglazurní malovanou výzdobou (obr. 7:2).

Ve skladbě okrajů dominují typy a varianty přehnutých okrajů, objevují se dále znovu okruží a ojediněle i prstované okraje hrnců. Mísy mají zpravidla charakteristické tvary raně novověkých okrajů, včetně tzv. talířovitého podokrají. Z výzdobných motivů se ještě udržuje radélko složitých geometrických motivů, ale výhradně na redukční keramice. Vnitřně glazovaná keramika je zpravidla zdobena jen jednoduchými rytými rýhami na podhrdlí a vzácně podglazurní malbou. Podobnou skladbu vykazují i jiné soubory z přelomu pozdního středověku a raného novověku z jižních Čech, například z Tábora (Krajíc 1998) či Českého Krumlova (Preusz a kol. 2014, 59-77). 

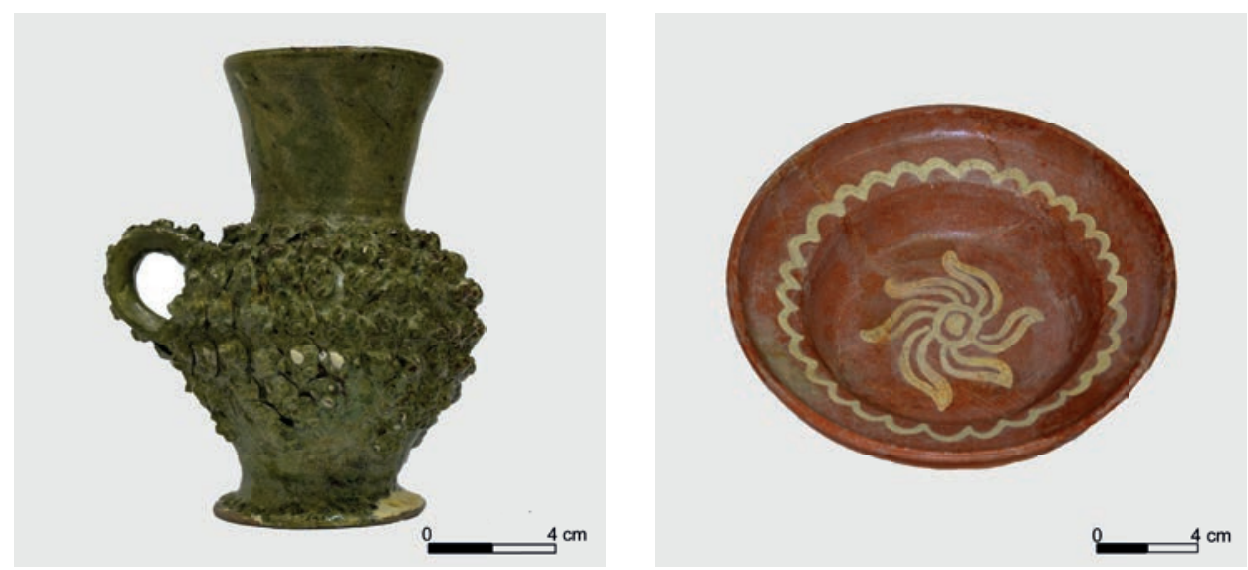

Obr. 7. České Budějovice, nádvoří městské radnice. 1 - raně novověký glazovaný džbán s plastickými nálepy, 2 - cihlově červená talířovitá mísa s podglazurní malbou. Foto L. Čapek.

Abb. 7. České Budějovice, Hof des städtischen Rathauses. 1 - frühneuzeitlicher glasierter Krug mit plastischen Aufschmelzungen, 2-ziegelrote Tellerschale mit Unterglasurmalerei. Foto L. Čapek.

\subsubsection{Novověké dýmky}

V 19. a 20. století tvoří novou složku materiální kultury dvojdílné keramické a trojdílné porcelánové dýmky (obr. 8). Ty přináší především svědectví o šíření kuřácké kultury do sociálního prostředí českobudějovické městské radnice (Preusz 2015a). Nejstarší exempláře v souboru zastupují světlé dvojdílné dýmky (s identifikačními kolky) vyrobené ve východoevropském výrobním okruhu (Čurný-Šimčík-Bielich 2013, 86, obr. 1). Konkrétně jde o nález válcovité hlavičky, která se směrem vzhůru rozšiřuje a ve spodní části je dekorována rytou výzdobou a geometrickým ornamentem na plastické liště. Není vyloučeno, že jde o produkt rakouských dílen, patrně v Theresienfeld (obr. 8:1). Další skupinou dýmek jsou dva zástupci typu „Cafe““, který byl produkován v oblasti kolem Kolína nad Rýnem, v jižním Německu a Rakousku-Uhersku (Vyšohlíd 2009, 984). První je hlavička šestiúhelníkového průřezu dekorovaná pomocí plátna (obr. 8:2). V druhém př́ípadě jde o exemplář s plastickým žebrováním s inskripcí na levé straně krčku „S E“, kterou se nepodařilo korelovat s historickým významem (obr. 8:3). Porcelánové trojdílné dýmky pochází z druhé poloviny 19. až počátku 20. století. Zdobeny jsou pestrobarevným malovaným dekorem. Znázorňují témata jako láska mezi myslivcem a dívkou, probouzení jara a období svádění či krajiny v kombinaci se zvířaty (obr. 8:4-10). Portrétní motivy zastupuje dýmka s podobiznou císaře Karla I. Habsburského (1887-1992, vládl 1916-1918) a inskripcí „Kaiser Karl“ (obr. 8:11). Zajímavostí je nález bronzových dekorativních doplňků k trojdílné dýmce $\mathrm{v}$ podobě poklice $\mathrm{s}$ otvory $\mathrm{k}$ přiklápění hlavičky, řetízku a bronzové plakety s motivem běžící lišky.

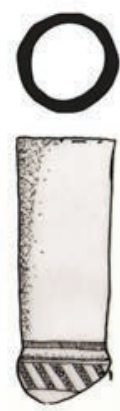

1
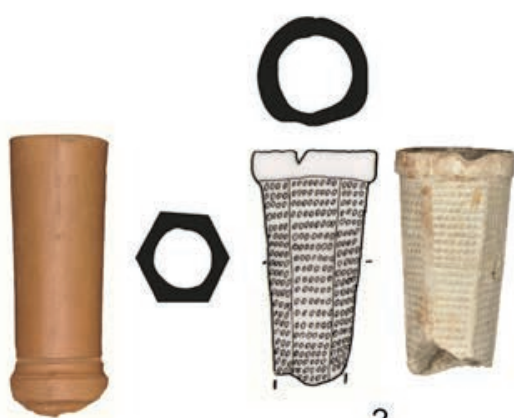

2
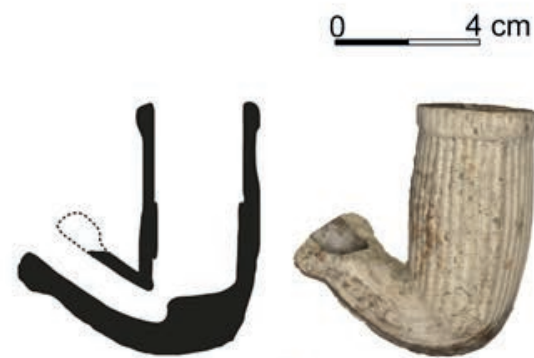

3

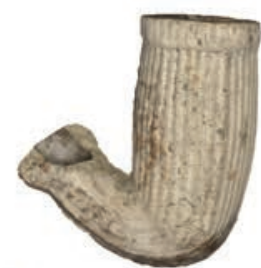



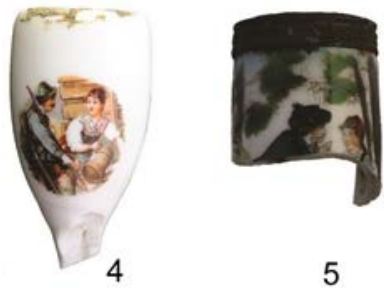

5

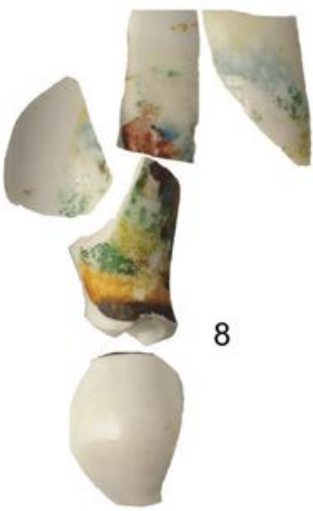

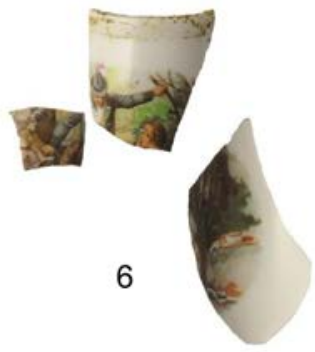
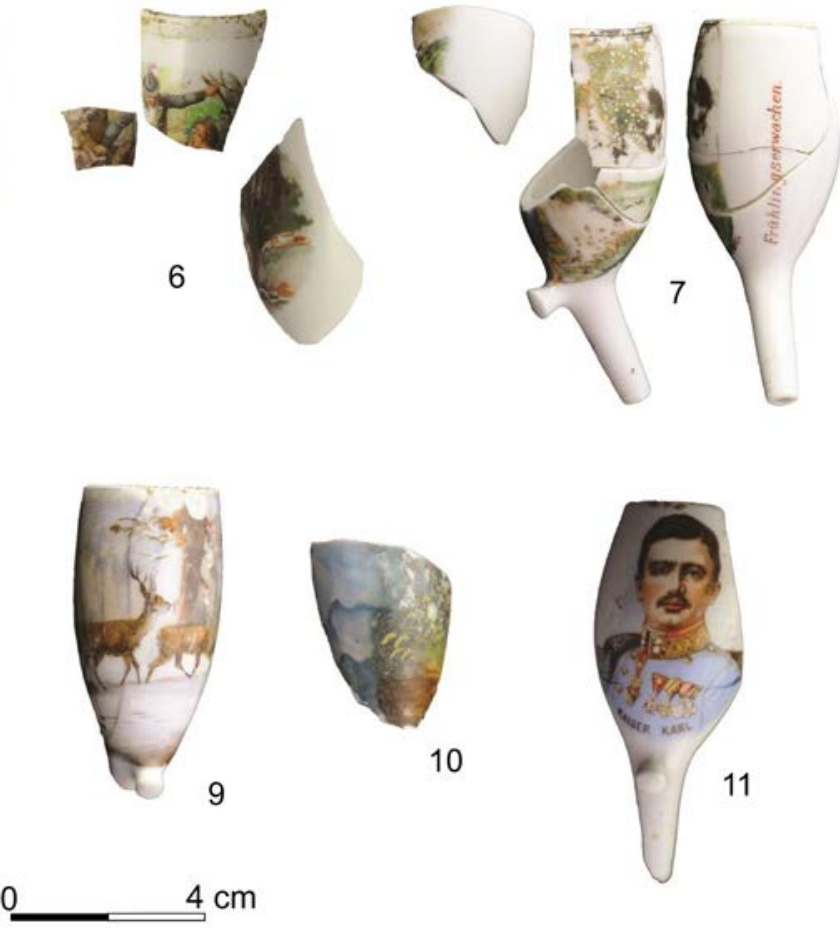

10

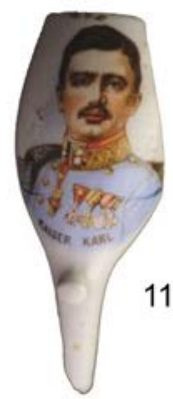

Obr. 8. České Budějovice, nádvoří městské radnice. Novověké keramické dýmky 19.-20. století. Foto K. Paclíková. Abb. 8. České Budějovice, Hof des städtischen Rathauses. Neuzeitliche Keramikpfeifen des 19.-20. Jhdts. Foto K. Paclíková.

\subsubsection{Kamnářská keramika}

Soubor kamnářské keramiky je na rozdíl od souboru užitkové keramiky nepočetný a bylo rozpoznáno pouze několik základních tvarů kachlů. Nejpočetnější kategorii tvoří nádobkové kachle s uzavřeným dnem a otevřeným ústím, jejichž vyhřívací funkce spočívala $\mathrm{v}$ zahřívání dna a pláště kachle ohněm zevnitř kamen a sáláním tepla do místnosti otevřeným ústím (Krajíc 1997, 23; Orna 2005, 9).

Nalezené nádobkové kachle byly vyrobeny většinou z režné hrnčiny redukčního nebo oxidačního výpalu a bylo mezi nimi rozlišeno několik základních profilací ústí zpravidla v podobě přímého mírně vykloněného ústí na horní ploše se seříznutým nebo mírně zaobleným a zesíleným okrajem. Na těle většiny kachlů se nacházely záchytné šroubovice a vnitřní obvodové lišty. Zlomky kachlů byly také zpravidla očazeny; dna kachlů nesou místy stopy po podsýpce (obr. 9).

Ve výplni studní z městské radnice bylo nalezeno celkem pět celých rekonstruovaných nádobkových kachlů; z toho jeden náleží ke kategorii dlouhých kachlů (obr. 9:2), dva ke středním (obr. 9:1-5) a dva ke krátkému tvaru podle jejich horizontálního uložení v kamnovém tělese (obr. 9:3-4). Podle plochy ústí byly rozděleny takto: jeden kachel s velkým ústím, tři se středně velkým ústím a jeden s malým ústím (podle Hazlbauer-Richter 1990, 418-420). U čtyř kachlů bylo ústí čtvercové $\mathrm{s}$ mírně prohnutými bočními stěnami - v jednom případě jsou rohy mírně zevně vytažené z boků, jeden měl kruhové ústí. Podle typologie Z. Smetánky lze kachle střední velikosti s pravoúhlým ústím označit za tzv. tyglíkovité, delší kachle s kruhovým ústím za tzv. pohárovité (Smetánka 1969, 234-238). Všechny nádobkové kachle měly kruhové dno. Středový úhel nebyl u těchto kachlů měřen. Podle kontextu, tj. podle jejich výskytu se středověkou keramikou je možné kachle datovat od 14. do první poloviny 15 . století. Tvarově podobné kachle byly nalezeny v zánikovém horizontu Sezimova Ústí z roku 1420, ale obecně přesnější datace nádobkových kachlů je problematická (Hazlbauer-Richter 1990, 432). 
Vývojově mladší komorové kachle se dochovaly pouze ve zlomcích, jejich obrazovou náplň se nepodařilo až na výjimky rekonstruovat (rytír̆ na koni s kopím a pětilistou rožmberskou růží, viz obr. 9:7 - srov. Krajíc 2005, 103-110, 126); u pozdně středověkých až raně novověkých komorových kachlů převažovaly rostlinné motivy a různě stylizované motivy (obr. 9:6). Zastoupeno bylo také několik zlomků reliéfních tvarů renesančních římsovitých kachlů, které byly glazovány nejčastěji sytě zelenou barvou na vnitřním povrchu a opatřeny rostlinnou obrazovou náplní, a dále několik zlomků kachlů s centrálním medailonem.
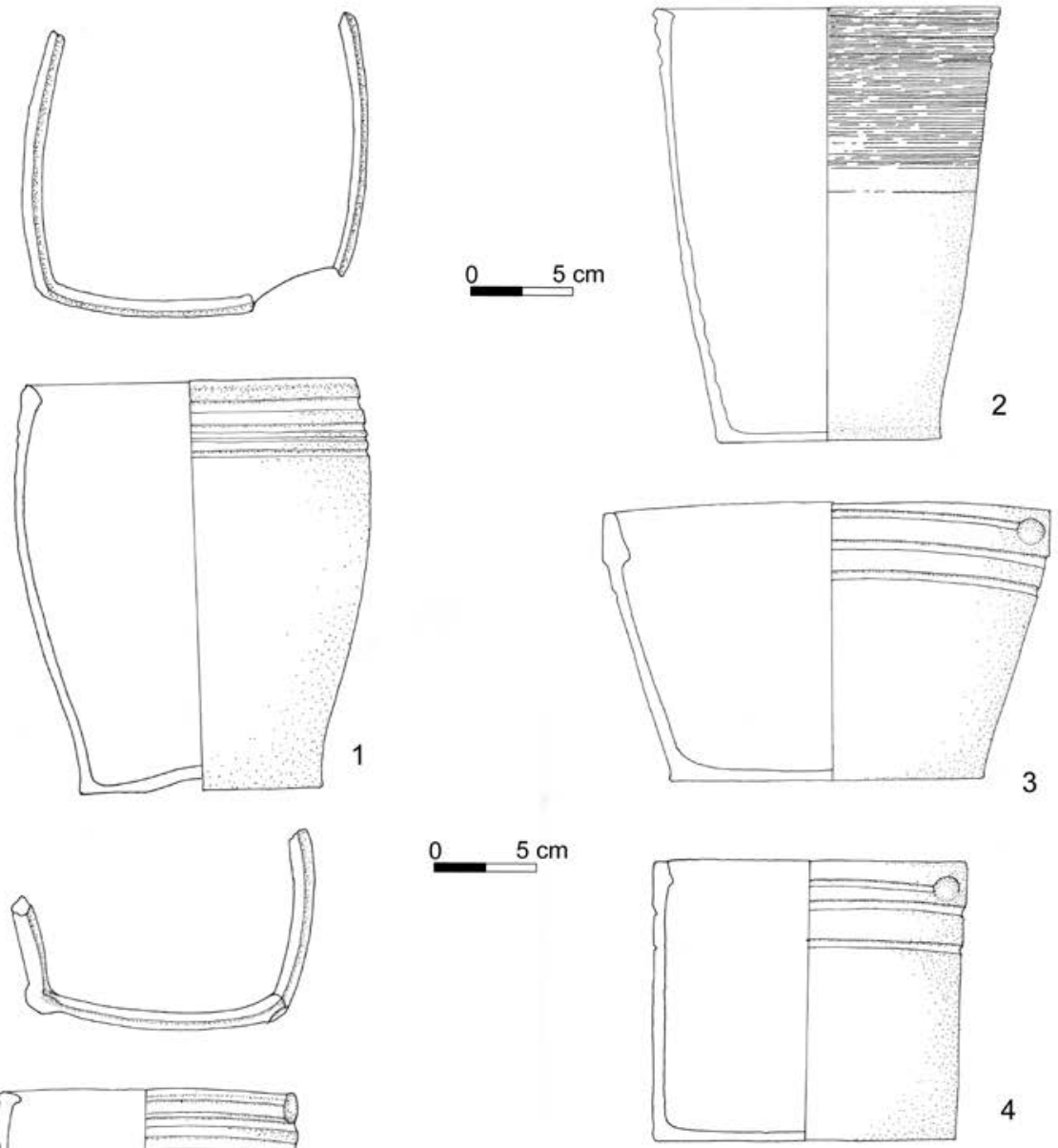

4
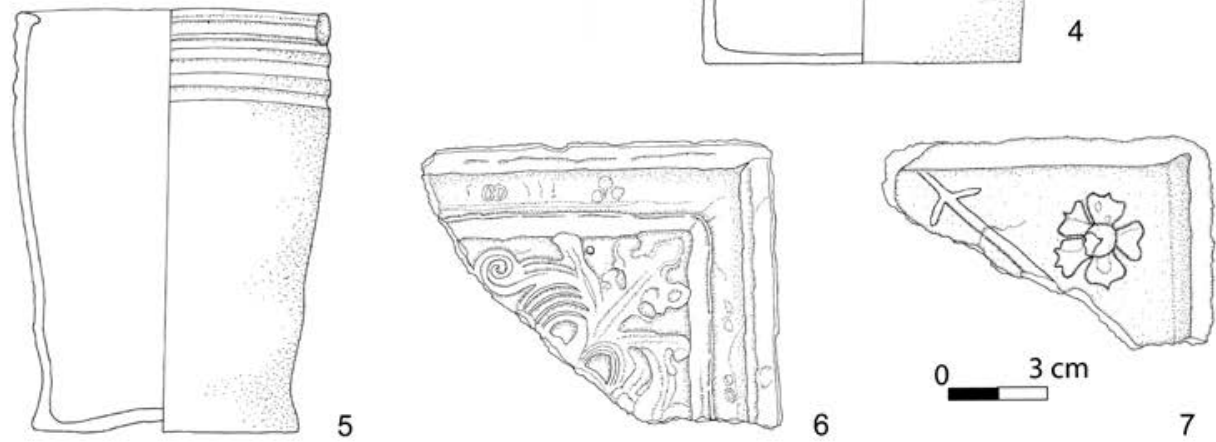

Obr. 9. České Budějovice, nádvoří městské radnice. Tvary nádobkových kachlů. Kresba L. Čapek.

Abb. 9. České Budějovice, Hof des städtischen Rathauses. Gefäßkachelformen der Funde. Zeichnung L. Čapek. 


\subsection{Sklo}

Nálezový soubor středověkých až raně novověkých skel z městské radnice zahrnuje více než 500 zlomků užitkového dutého a plochého skla, z toho pět slepitelných torz větších dutých nádob. Nejvíce nálezů skel pochází především z výplní studní - obj. $2 / 2$ na parcele $A$ domu čp. 1 a obj. 1/21 na parcele domu čp. 2. Další početnější soubor pochází také z výplně obdélného objektu obj. 1/20 interpretovaného jako odpadní jímka. Většina skel se dochovala ve značně fragmentárním stavu, s čímž souvisí i problematické určování jednotlivých typů výrobků.

V nálezových souborech se vyskytovala jak draselná skla s charakteristickou nazelenalou barvou, tzv. lesní sklo, tak i transparentní bezbarvá nebo mírně nažloutlá draselno-vápenatá skla. Většina zlomků byla více či méně zasažena odskelněním, tj. vylouhováním alkálií, projevujícím se například irizující korozní vrstvou, duhovým povlakem, důlkovou korozí či opakně mléčně bílou korozní vrstvou.

Ke stolování byly ve středověku a novověku používány různé tvary dutého skla - pohárů, číší, džbánů, konvic a lahví. Stolní sklo je v souboru z městské radnice zastoupeno zlomky nápojového skla tvarovaného a zdobeného různými hutními a zušlechtovacími technikami, zejména jde o vytváření různých nálepů, natavování vláken a ojediněle i optických dekorů či zdobení malbou.

Nejčastější typ středověkého skla z městské radnice tvoří vysoké číše českého typu (až 83 \%). Zlomky číši se ojediněle objevovaly v kontextech již od sklonku 13. století, nejpočetnější nálezy však pocházejí ze studní datovaných i na základě keramiky do přelomu 14. a 15. až poloviny 15. století. Většina číší patří k nejrozšířenějším typům vyšších válcovitých píštalovitých tvarů, jejichž tělo se směrem ode dna mírně rozšiřuje a plynule předchází do mírně rozšířeného ústí (Frýda 1988, 175-187). Dochovala se i torza zvonovitých patek s vpíchnutým dnem, v jednom př́ípadě i s technologickou stopou - otiskem kleští. Na těle čiší českého typu se nachází natavovaný dekor v podobě drobných perlových nebo svinutých nálepů umístěných více či méně rovnoměrně na štíhlém těle (obr. 10). Svinuté nálepy jsou přičítány středočeskému dílenskému okruhu (Hejdová-Nechvátal 1967, 442, 457-459), ale vyskytují se i v Mostě, Brně či Opavě (Černá 1995, 251; 2002, 104; Sedláčková 2004, 243-244). V souboru se až na výjimky nevyskytly tzv. srpečkovité nálepy považované za typický projev západočeské oblasti, které se v jižních Čechách objevují na číších českého typu z Tábora, domu čp. 220 (Krajíc 1998, 185-189). Kromě nálepů se na válcovitých číších objevuje i hutní dekor v podobě horizontálních natavených vláken oddělujících ústí a dno těla číše (obr. 10:1,3).

Kromě číší českého typu byly v souboru skel zjištěny i menší číše s nálepy (tzv. Nuppenbecher) vyrobené ze skla čiré nebo světlé barvy, s menšími šnekovitými nálepy (Baumgartner-Krueger 1988, 192-209) a dále číše s tzv. koštálovitými nálepy, v německé literatuře označované jako krautstrunky, vyznačující se specifickým hutním dekorem tvořeným velkými plochými, hrotitě vytaženými nálepy, vyrobené ze skloviny sytě zelené barvy. Původ těchto menších číší a číšek s nálepy lze hledat v oblasti jižního a západního Německa a Rakouska (Baumgartner-Krueger 1988, 296-298; Černá 1996, 35; Stadler-Reitmaier 2003, 191-192, 194). Fragmenty krautstrunku byly nalezeny v zásypu cihlového objektu datovaného do první poloviny 15 . století.

Zvláštní druh skla pak představuje zlomek těla číše s optickým foukaným dekorem do formy s drobnými čočkovitými vypouklinami z bezbarvého, mírně nažloutlého skla. Na vnější straně se nachází zbytek malby žlutozeleným emailem. Z našeho území pochází číše s optickým dekorem v podobě bodů z Prahy - Starého Města (Prokopová 2014, 136-137, Abb. 6:7 a Abb. 8) a Brna, kde je datována do období let 1270-1350 (Sedláčková 2003, 128-129, Taf. 1/IV.4.1, Taf. 2/IV.4.1, Taf. 3/IV4.1). Ovšem vzhledem k tomu, že se optický dekor v podobě čoček objevuje i v renesanci, nelze vyloučit mladší původ (Drahotová a kol. 2005, 163), který by potvrzovaly i nálezové okolnosti.

$\mathrm{Z}$ dalších tvarů skel se pak vyskytl i fragment ústí a okraje kutrolfu, zvláštního typu lahve s hrdlem tvořeným několika spojenými rourkami. Z Čech a Moravy pocházejí jejich nejstarší nálezy ze sklonku 14. a zejména pak z 15. století (Černá a kol. 1994, 74; Sedláčková 2004, 249). Fragment kutrolfu byl však uložen v druhotné pozici v novověké navážce.

Zvláštní typ skla představuje torzo hrdla lahve s optickým foukaným dekorem v podobě šikmých žeber (obr. 11). Kónické hrdlo plynule přechází v nedochované, pravděpodobně hruš- 

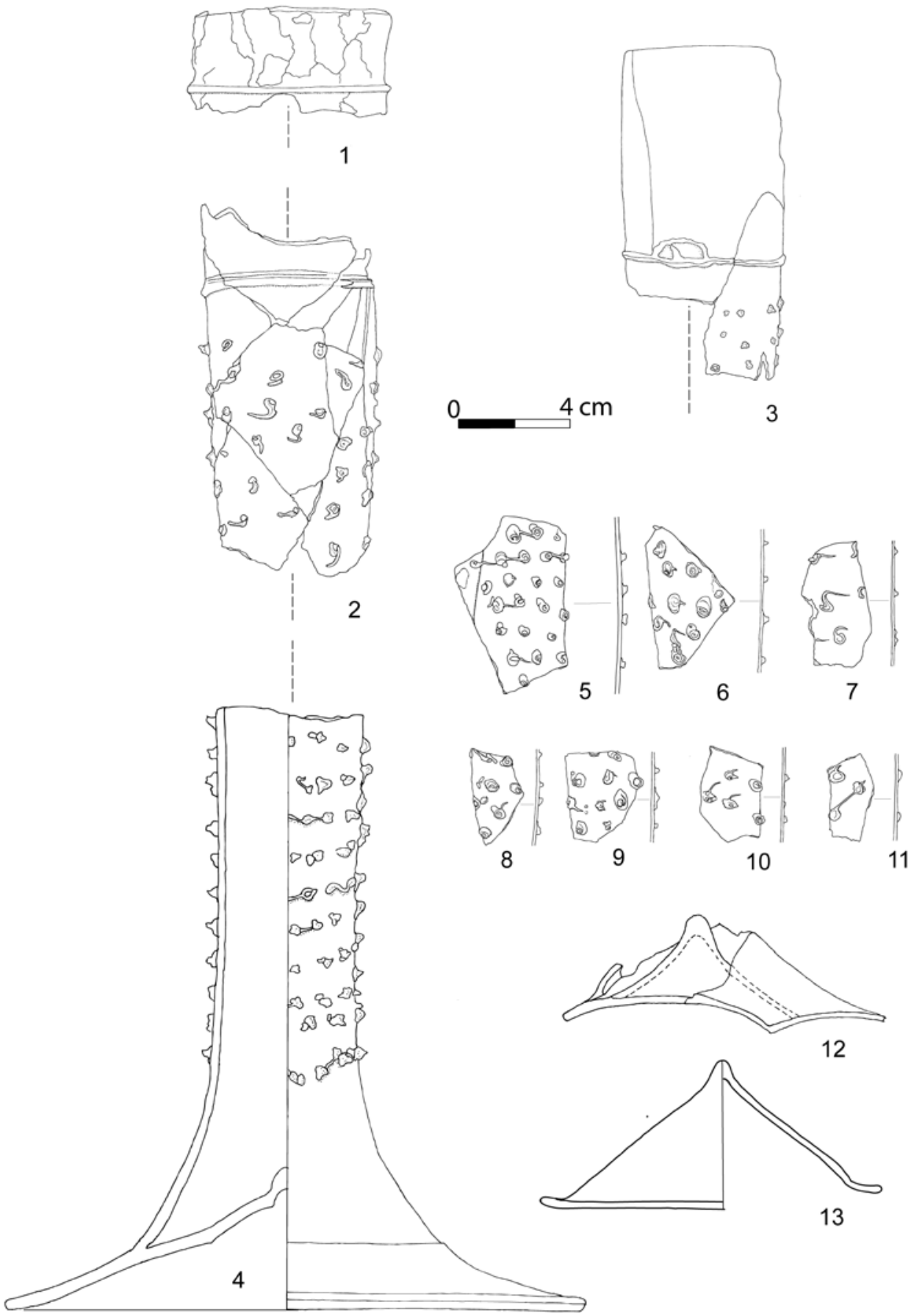

Obr. 10. České Budějovice, nádvoří městské radnice. Torza číš́ českého typu. Kresba L. Čapek.

Abb. 10. České Budějovice, Hof des städtischen Rathauses. Torso eines Bechers böhmischen Typs. Zeichnung L. Čapek. 


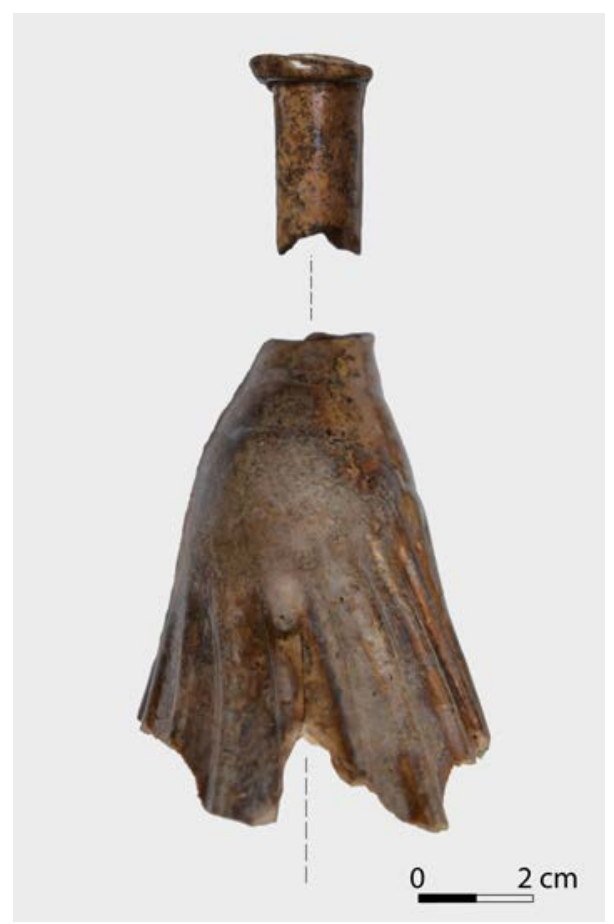

Obr. 11. České Budějovice, nádvoří městské radnice. Torzo žebrované lahve. Foto L. Čapek.

Abb. 11. České Budějovice, Hof des städtischen Rathauses. Torso einer gerippten Flasche. Foto L. Čapek. kovité tělo. Optický dekor v podobě svislých žeber vzniklých z předforem se nejčastěji vyskytuje kolem první čtvrtiny 15. století (Černá a kol. 1994, 74; Drahotová a kol. 2005, 176). Podobné nálezy lahví s optickým dekorem jsou známé např́íklad z Plzně (Frýda 2007, 39) nebo z Brna (Sedláčková 2003, 128-129, Taf. 1/III.1, Taf. 2/IV.4.1). Lahve s optickým žebrovaným hrdlem jsou známé $\mathrm{z}$ nálezů v Horním Rakousku, kde jsou datovány do 16. století (Tarcsay 2003, 170, Abb. 7). Tomuto datu odpovídají i nálezové okolnosti zásypu studny s nálezem fragmentu lahve. Do nejmladšího (barokního) období lze datovat válcovitou lahev s úzkým hrdlem a dovnitř vpíchnutým dnem, vyrobenou $\mathrm{z}$ tmavě zeleného skla. Lze ji datovat někdy kolem první poloviny 18. století (srov. Gelnar 2014, 324).

Kromě dutého skla pochází z městské radnice také nálezy okenního skla, nejčastěji ve formě okenních terčů či okenních destiček, zpravidla trojúhelníkovitého tvaru. Okenní terče se vyskytují dvojího druhu, a to jak s plochým okrajem, tak i s okrajem krátce přehnutým, vytvářejícím tak zesílený okraj (srov. Gelnar 2014, 319). Datovány jsou převážně od poloviny 14 . století do 15 . století, kdy se zasklívání oken ve středověkých městech stávalo běžnou záležitostí (Černá 2002, 30).

Na základě typologického vývoje dutých a plochých skel a jejich nálezových okolností můžeme sledovat chronologii a tvarovou proměnu skel na nádvoří městské radnice. Číše českého typu se objevují v městských domácnostech již od sklonku 13. století až do poloviny 15. století. V 15. století se setkáváme s číšemi s velkými koštálovými nálepy, pro které se vžilo označení krautstrunk, a pravděpodobně i s kutrolfy. Na přelomu 15. a 16. století je doložena žebrovaná láhev. V 16. století dochází k výraznému ústupu skel, objevují se převážně pouze fragmenty plochých skel - okenních terčů, výjimečně číší s optickým dekorem.

\subsection{Předměty ze železa a barevných kovi̊}

Z archeologického výzkumu pochází také soubor předmětů ze železa a barevných kovů. Obsahoval téměř všechny základní skupiny předmětů vztahující se k životnímu standardu bydlení v měšt’anské domácnosti, domácí výbavě či provozně-hospodářskému zázemí. Na rozdíl od souborů železných artefaktů ze středověkých vesnic (např. Belcredi 1989, 437-472; 2006, 345-378) tvoří výrazně méně početný soubor pouze s úzkým spektrem typologických skupin, které dokládají, že většina železných artefaktů náleží do kategorie tzv. ztrátových či zapomenutých předmětů. Nálezový soubor byl rozdělen do osmi skupin: stavební kování a uzavírací mechanismy, využívání zvířecí síly, nástroje a řemesla, zemědělské nástroje, předměty osobní výbavy a mobiliář, provozně-obchodní předměty a militaria.

Největší zastoupení měly železné předměty ve skupině stavebního kování, kam patří výrobky stavebně-konstrukčního charakteru, jež plnily funkci spojovací, připevňovací, uzavírací a bezpečnostní (zabezpečovací), nebo byly na sebe funkčně a konstrukčně vázány - zámek a klíč (Krajíc 2003, 61). 
Nejpočetnější z předmětů stavebních byly železné hřebíky, které sloužily především k uchycení konstrukcí a jejich částí. Typologicky byly rozděleny na kategorie hřebíků s horizontální plochou či vypouklou hlavou nebo s tzv. krŕ́dlatou hlavou. Dále se v souboru nacházely hřebíky s vertikální hlavou, mezi nimiž bylo rozlišeno několik hřebíků tzv. podkováků a šindeláků (srov. Krajíc 2003, 64-67). Početná byla i skupina hraněných hřebíků bez hlavy, někdy označovaných jako tzv. klínce (Krajíc 2003, 68). Z dalších předmětů ve skupině stavebního kování byly identifikovány jednoramenné a dvouramenné skoby, a také jedno oko s trnem (Krajíc 2003, 74-75).

Mezi součásti uzavíracích mechanismů patří otočné klíče. V souboru železných předmětů z městské radnice jsme zaznamenali tři nálezy otočných klíčů, z toho jeden celý klíč s oválným okem, osmibokým plným dříkem a výrazně prořezávanou bradou (obr. 12:1). Tento typ klíče je datován podle nálezů otočných klíčů ze Sezimova Ústí do druhé poloviny 14. století (Krajíc 2003, 92-93). O posunu jeho datování vypovídají nálezové okolnosti, nebot’ klíč byl nalezen v zásypové vrstvě nad suterénem datované do počátku 14. století.

Další skupinu železných předmětů představují nálezy, které dokládají využíání zvířceí síly $\mathrm{k}$ účelům tažným a jezdeckým. Z městské radnice pocházejí dvě železné podkovy, které však byly ve velmi špatném stavu, jenž znemožňuje jejich bližší typologické určení (obr. 13:2). Dále se dochovala část dvouramenného udítka kruhového průřezu se zúženou částí směrem ke středověkému kloubu (obr. 13:3). Podle typologie udidel ze Sezimova Ústí lze nález zařadit do 14. století (Krajíc 2003, 113-114, obr. 100). Ke spojení otěží, eventuálně ohlávky s udítkem sloužily železné kruhy (obr. 13:4-5), z nichž dva exempláře jsou v souboru zastoupeny (Krajíc 2003, 111). Do skupiny dopravních prostředků - součástí vozů patří nález zákolníku s vertikální hlavou srdcovitého tvaru a kruhovým dř́kem (obr. 12:6; Krajíc 2003, 197-198; Belcredi 2006, 372, tab. XLVII, obr. 10-13).

Z železných řemeslných nástrojů se dochovaly pouze dva předměty, a to průbojník s dříkem kruhového průřezu přecházející v dlouhé zploštělé tělo obdélného průřezu ukončené ostrým hrotem (obr. 12:4) a pravděpodobně dláto $\mathrm{s}$ ohnutým koncem a s trnem pro nasazení dřevěné rukojeti (obr. 12:5; srov. Krajíc 2003, 150-151). Mezi zemědělské nástroje patří tři exempláře železných nápichových hrotů (hnojných?) vidlí s plochou špicí a tulejovitým ukončením (obr. 13:7-9), které jsou známé především z kontextu zaniklých středověkých vsí (Belcredi 2006, 357; Měchurová 2008, 139-140). Nalezena byla i zlomená čepel srpu (obr. 14:10).

Mezi předměty běžné denní potřeby a vybavení domácností patří nože. Ze souboru železných předmětů pochází jeden dlouhý jednobřitý nůž s plochou rukojetí - řapem a rovnou čepelí, která se směrem k hrotu kónicky zužuje. Na rukojeti se dochovalo obložení pomocí dřevěné střenky, která byla připevněna spojovacími nýty (obr. 12:6). Nůž je podobný typům nožů (typ II) ze Sezimova Ústí, odlišuje se však neodsazením ostř́i od rukojeti (srov. Krajíc 2003, 204-205). Dále byla nalezena čepel kratšího jednobřitého nože s obloukovým hřbetem a trnovitým řapem (obr. 12:7). Zvláštní typ nože představuje dochovaná železná rukojet’s dřevěnou střenkou připevněnou nýty $\mathrm{z}$ barevného kovu. Konec rukojeti je $\mathrm{v}$ týlu ukončen profilovaným plechem z barevného žlutého kovu zdobeným vybíjením (obr. 14:1). Tato subtilní rukojet’ pochází z příborového nože určeného ke stolování (srov. Krajíc 2014, 350, 355, obr. 4:4-18).

Ke skupině militarií lze zařadit dvě deformované železné segmentové koule o průměru $2,0-2,3 \mathrm{~cm}$ a olověné kuličky o průměru $1,8 \mathrm{~cm}$. Železné kuličky těchto průměrů mohly sloužit jako projektily pro tarasnice či hákovnice, naopak olověné kuličky jsou považovány za projektily lehčích typů ručnic - píšt’al a jsou mladší (Nekuda 1985, 147; Wagner-Drobná-Durdík 1956, 88).

Poměrně četné byly předměty osobní výbavy, zejména v kategorii součástí oděvů. Nejzajímavějšími jsou nálezy součástí článkových kovových (bronzových) opasků, a to zdobného spojovacího podkovovitého článku pásové zápony se sukovitě zakončenými rameny a pečetítkovými konci, který sloužil k zavěšování nejrůznějších osobních předmětů, a dále tří páskových zápon jazykovitého tvaru s připojovacím kloubem a dvojicí nýtů k upevnění, zdobených vybíjeným rostlinným ornamentem na vnější straně (obr. 14:2). Tyto články především ženských opasků jsou v německé převážně etnografické literatuře označovány jako tzv. Brautgürtel - opasek nevěsty (Harder 2010, 5-6). Dosavadní nálezy těchto opasků z Čech a Moravy jsou datovány do renesančního až manýristického období od 16. do poloviny 17. století (Musil 2012, 101; Měchurová 2012, 763-764). 

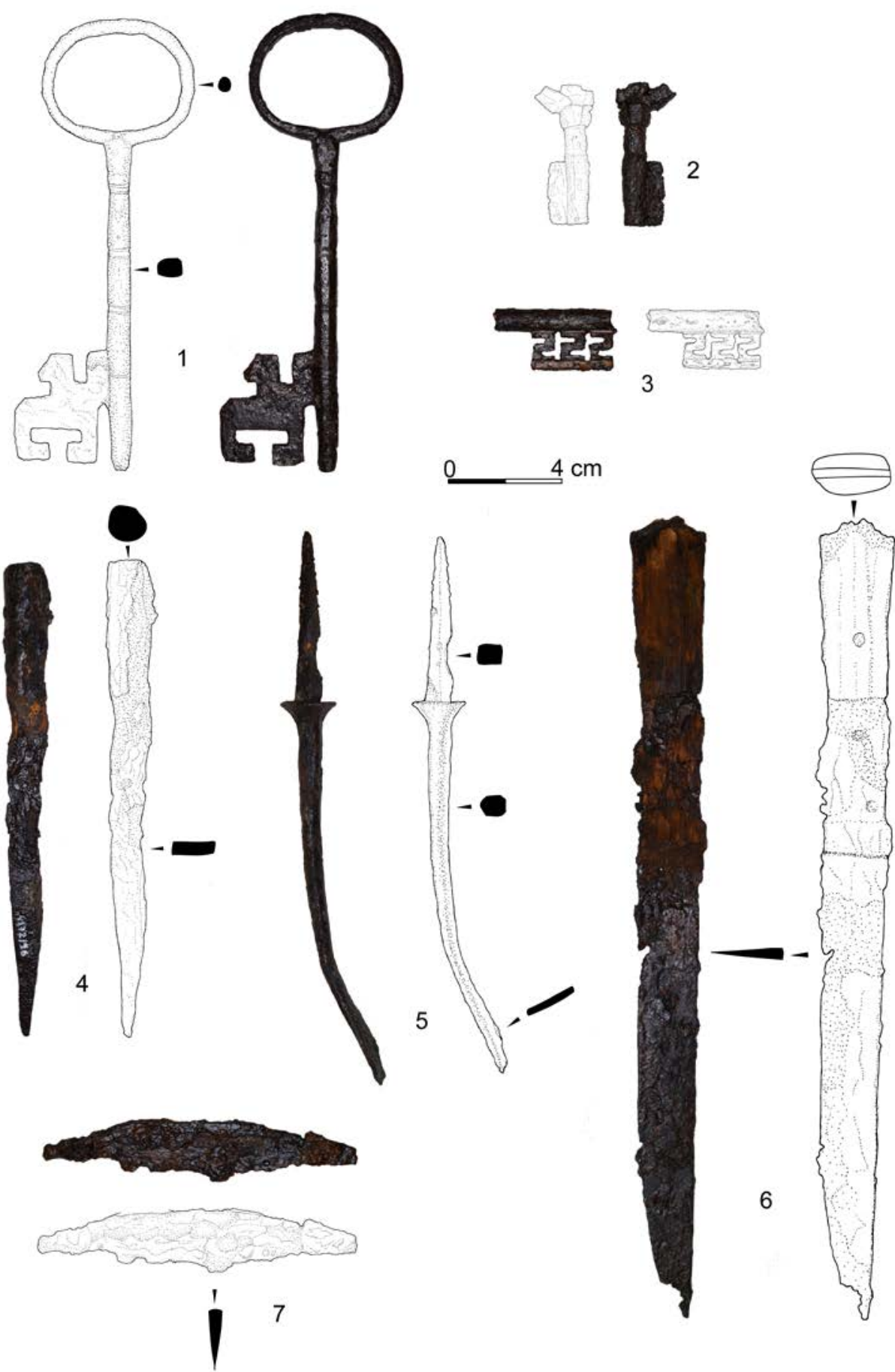

\section{2}

3

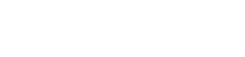

6

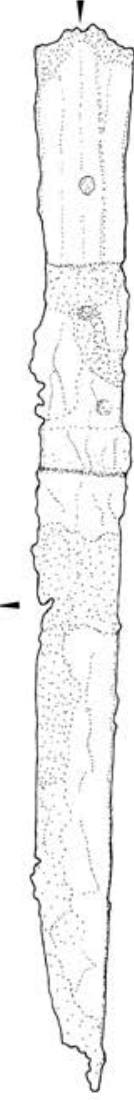

Obr. 12. České Budějovice, nádvoří městské radnice. Železné předměty - uzavírací mechanismy, předměty osobní výbavy a řemeslnické nástroje. Kresba E. Peterková, foto L. Čapek.

Abb. 12. České Budějovice, Hof des städtischen Rathauses. Eisengegenstände - Schließmechanismen, Gegenstände der persönlichen Ausstattung und Handwerksgeräte. Zeichnung E. Peterková, Foto L. Čapek. 

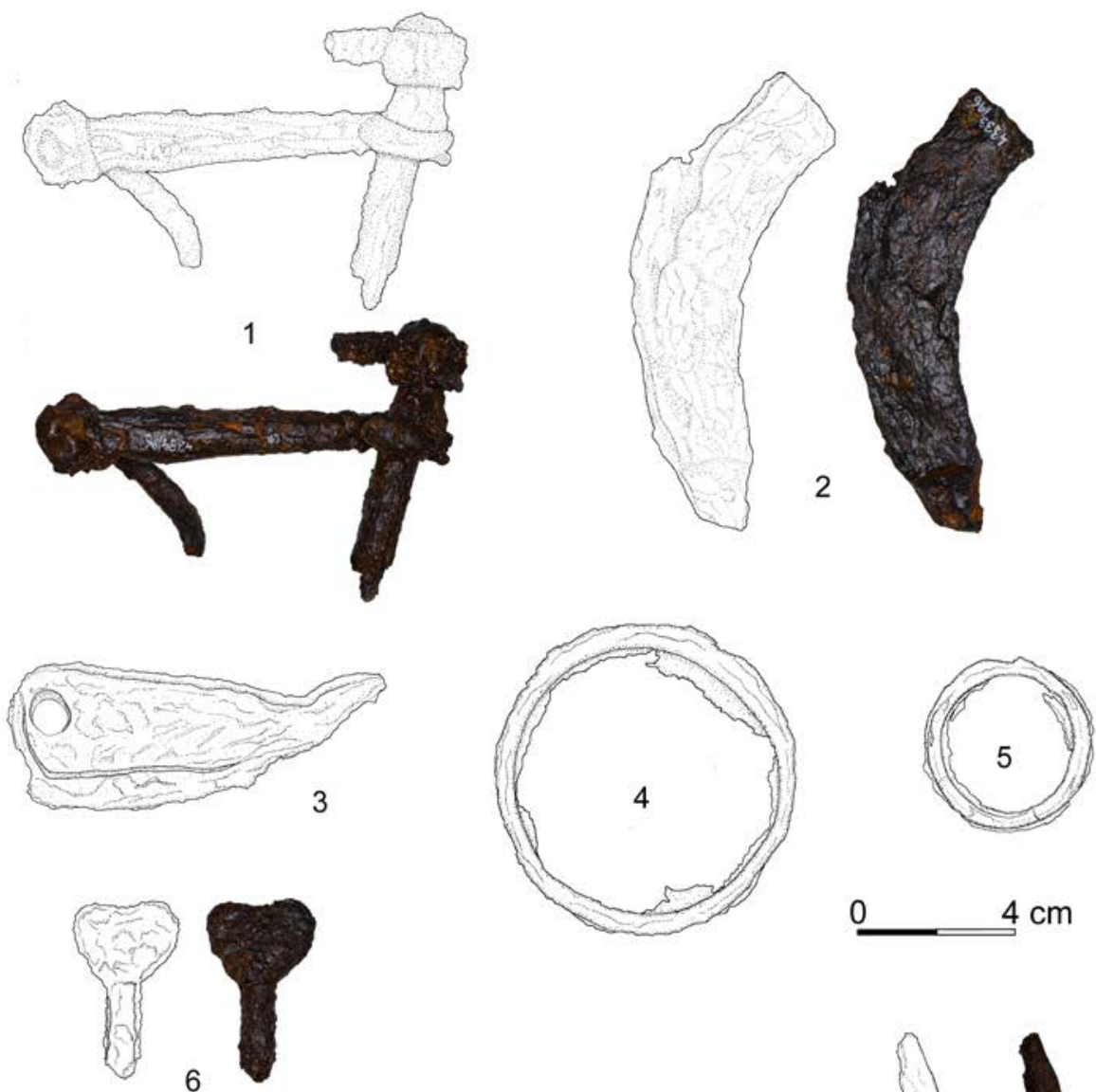

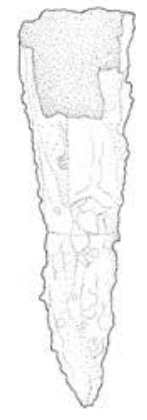

7

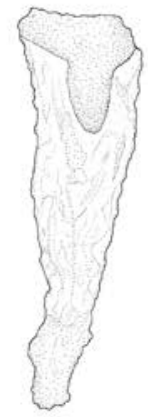

8
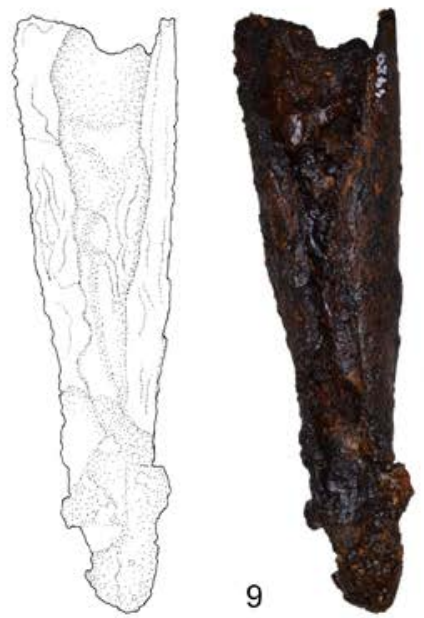

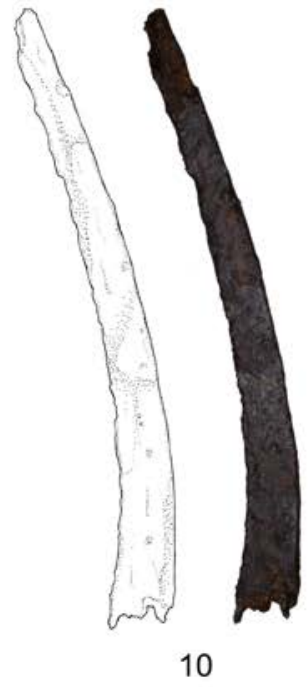

Obr. 13. České Budějovice, nádvoří městské radnice. Železné předměty - vybavení jezdce a koně, součásti vozu a zemědělské nástroje. Kresba E. Peterková, foto L. Čapek.

Abb. 13. České Budějovice, Hof des städtischen Rathauses. Eisengegenstände - Pferd- und Reiterausstattung, Wagenbestandteile und landwirtschaftliche Geräte. Zeichnung E. Peterková, Foto L. Čapek. 
Výrobou opasků a jejich jednotlivých částí se zabývali specializovaní řemeslníci - pasíři - cingulatores, zonatores; něm. guertler (Musil 2011, 2).

Mezi dalšími předměty z barevných kovů vynikají drobné nášivky a spínadla oděvů, háčky či kulovité knoflíky s poutkem (srov. Krabath 2001, 196-210). Unikátní je zejména hvězdicovitá nášivka na oděv se zadním poutkem, která sloužila jako ozdoba šatů (obr. 14:3). Soubor drobných kovových artefaktů rozšiřuje dosavadní poznání o předmětech z barevných kovů jako součástech oděvů či osobní výbavy z městského prostředí (srov. Procházka 1990, 99-109).
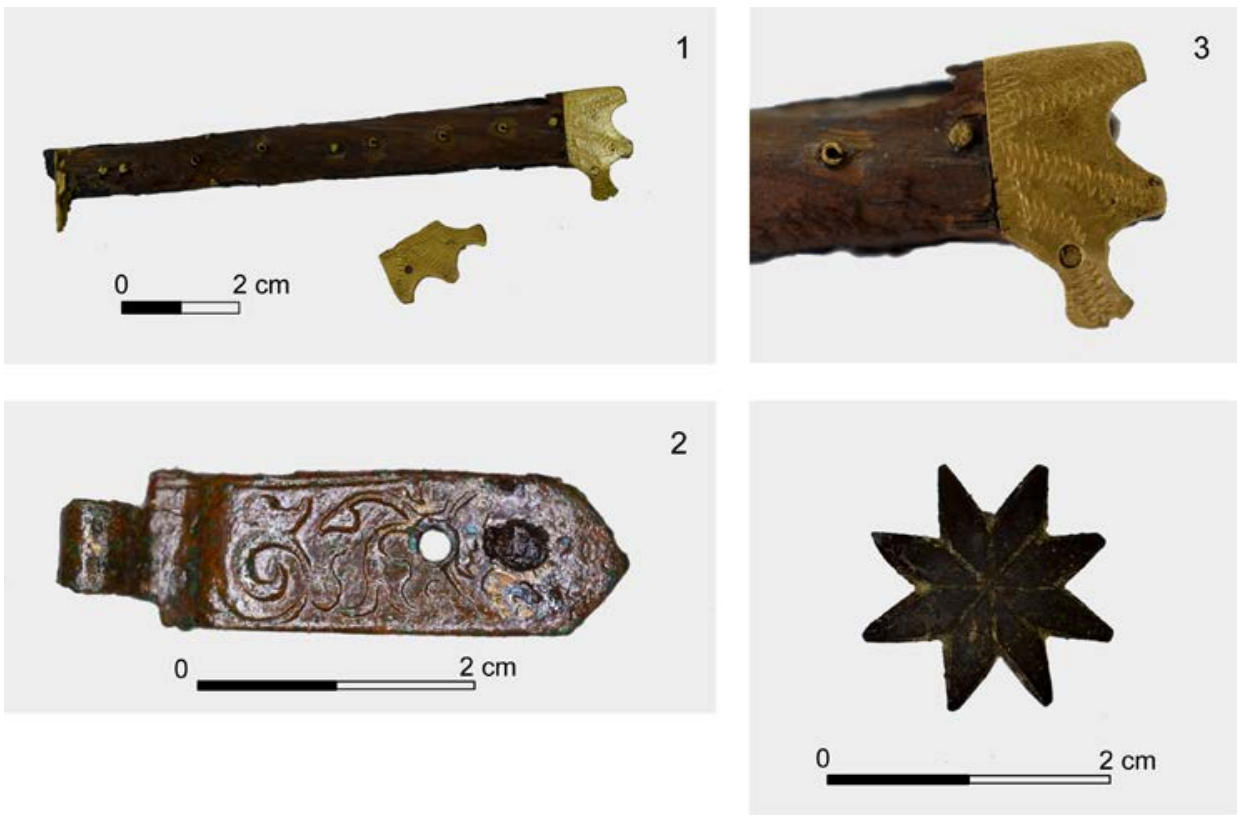

Obr. 14. České Budějovice, nádvoří městské radnice. 1 - zdobená rukojet’ př́iborového nože, 2 - opasková zápona, 3 - nášivka na oděv. Foto L. Čapek.

Abb. 14. České Budějovice, Hof des städtischen Rathauses. 1 - verzierter Griff eines Besteckmessers, 2 - Gürtelschnalle, 3 - Kleidungsaufnäher. Foto L. Čapek.

\subsection{Mince}

Z nádvoří českobudějovické radnice pochází nepočetná kolekce mincí z rozmezí 13. až 19. století. Kromě menšího souboru mincí ze zásypu zděného cihlového objektu jde zpravidla o ztrátové mince, které odrážejí manipulaci s mincemi nejen v domech (mince určil J. Militký).

Za nejstarší ražbu lze považovat fenik pasovského biskupství (Kellner 1997, 113, č. 36), který pochází z podlahové úrovně zadního traktu gotického domu. Tyto tzv. věčné feniky byly prakticky v nezměněné podobě raženy od druhé poloviny 13 . do první poloviny 14 . století. Na líci nesou obraz vlka kráčejícího doleva a biskupské berly, na rubu motiv zvířete kráčejícího doleva s oválným štítkem s křižem. Intenzivní import pasovských tzv. věčných feniků do jižních Čech těsně po roce 1300 dokládá depot z vrchu Javorník, k. ú. Lhota pod Rohanovem (Militký 2014). Je zřejmé, že tyto ražby byly zapojeny do lokálního peněžního oběhu, a to nepochybně také v Českých Budějovicích. Z prostoru nádvoří městské radnice pochází haléř typu koruna/lev, ražený v Kutné Hoře na přelomu vlády Karla IV. (1346-1378) a Václava IV. (1378-1419) asi v letech 1376-1383 (Hána 2005, 123, typ č. Vb).

Menší soubor mincí objevený ve dvoře radnice v Českých Budějovicích lze charakterizovat jako hromadný nález sestávající celkem ze sedmi mincí pocházejících ze zásypu zděného cihlového objektu obj. $1 / 4$, kde byly nalezeny v jedné vrstvě na ploše zhruba $50 \times 50 \mathrm{~cm}$. Jde o šest 
haléřů Vladislava II. Jagellonského (1471-1516) - zastoupeny jsou typy (podle Castelin 1932, obr. 1:1, 2, 3, 4? a 6). Tyto ražby reprezentují nejdrobnější nominály pozdně gotického peněžního grošového systému. Společně s nimi zde byl nalezen také haléř (Nechanický-Šafář 1983, 19-20, č. 12) ražený zřejmě před rokem 1485 v kladské mincovně Jindřichem z Münsterberku († 1498). Celý soubor zde byl nejspíše náhodně ztracen někdy na přelomu 15. a 16. století. Nelze vyloučit, že mince byly součástí menšího depotu uloženého v keramické nádobě, nebot' ze zásypu objektu pochází četná keramika druhé poloviny 15 . století. Pravděpodobněji však jde o náhodný ztrátový jednorázový rozsyp, např. nechtěně vysypaný měšec s penězi.

Do období přelomu 15. a 16. století lze datovat také fragment přesněji neurčitelného kutnohorského halére, pocházejícího z plochy výzkumu. Jedna ražba je zcela nedatovatelná. Ztrátové mince z období raného novověku reprezentuje přesněji neurčitelný 3krejcar ražený zřejmě Ferdinandem II. (1619-1637) či krejcar města Štrasburk z průběhu 16. století. Obě ražby pocházejí z vyšších stratigrafických úrovní již zmíněného objektu obj. 1/4. Nejmladší nálezový horizont ze dvora radnice reprezentují tři ztrátové měděné exempláře konvenční měny. Krejcar Marie Terezie ražený v roce 1760 ve Vídni byl zjištěn v sekundární pozici, krejcar Josefa II. ražený ve Vídni v roce 1780 pochází z podlahové úrovně strážnice, zřízené roku 1792. Krejcar Františka II. ražený v roce 1816 v kremnické mincovně pochází ze zásypu novověké vápenky.

Lze tedy shrnout, že mincovních nálezů ze dvora radnice je doloženo poměrně málo. Je otázka, do jaké míry je tento fakt ovlivněn metodikou výzkumu, při které ještě nebylo možné aplikovat kvalitní detektor kovů, ${ }^{3}$ a do jaké míry lze toto zjištění považovat za objektivní. V druhém př́ípadě by tak mohlo jít např. o náznak menší intenzity manipulace s drobnými peněžními nominály $\mathrm{v}$ tomto prostoru.

\section{Výpověd’ hmotné kultury o sociálním a ekonomickém postavení městských domácností}

Shromážděné a vyhodnocené soubory artefaktů jsou první ucelenou sondou do života obyvatel městských parcel a materiální kultury městských domácností v Českých Budějovicích v průběhu vrcholného/pozdního středověku až raného novověku, navíc v městských domech, které podle údajů berních knih a knihy lozunků z let 1396-1416 byly označeny za nejvíce oceňované. Měštané vlastnící dům na nádvoří městské radnice patřili podle výše přiznávaného majetku mezi nejbohatší vrstvu obyvatel (Borská-Urbánková 1964, 130). Průměrná hodnota domů v Českých Budějovicích se na přelomu 14. a 15. století pohybovala kolem 3,8 hřivny - na základě výpočtů podle údajů z berní knihy z let 1396-1416 (Čechura 1987, 4).

Získané soubory artefaktů lze rozdělit podle způsobu vzniku a formačních procesů do třech kategorií. V první z nich jsou soubory záměrně utvořené, vzniklé vyhozením či vyřazením (keramické nádoby, sklo), jež se zpravidla jako odpad dostávaly do výplní zahloubených objektů, které ztratily svoji funkci, jako jsou zahloubené stavby, hospodářské objekty, odpadní jámy a jímky, studny. Druhou kategorii tvoří artefakty ztracené či zapomenuté, zpravidla volně rozptýlené v sídlištním souvrství (převážně drobné předměty ze železa, barevných kovů a mince). Poslední kategorii tvoří předměty terciárně přemístěné v souvislosti se stavebními aktivitami, které se staly součástí stavebních vrstev - navážek, planýrek či zásypů; vypovídací hodnota těchto artefaktů je velmi snížena.

Poznávání sociálního a ekonomického života obyvatel městských domů je zpravidla závislá na povaze archeologických pramenů v záměrně utvořených nálezových souborech (srov. Klápště ed. 2002, 197). Materiální kultura je především odrazem každodenního života a běžných potřeb obyvatel na městských parcelách (srov. Buśko-Piekalski 1998). Nálezy skel, ale i středověké keramiky ukazují městské parcely jako místa spotřeby a konzumpce (srov. Klápště ed. 2002, 200).

Na základě rozboru středověké a novověké keramiky jako běžného „spotřebního“ zboží nelze na sociálně-ekonomickou výlučnost městských domů na nádvoří radnice př́liš usuzovat.

3 Během výzkumu byl sice použiván detektor kovů Zetex, avšak jeho technické parametry naprosto neumožňovaly zjištění drobných předmětů $\mathrm{z}$ barevných kovů. Většina mincí byla tedy nalezena při standardních metodách archeologického výzkumu - této kategorii nálezů však byla věnována značná pozornost. 
Grafitová keramika je uniformní a je nalézána i v jiných částech města a její užití je spojeno s prvními a druhými generacemi obyvatel po založení města v roce 1265 . Po jisté době ekonomické stagnace města, již předpokládáme do konce 13., či na přelomu 13. a 14. století (Čechura 1984, 65; Čechura-Razím 1988, 409), došlo ke změně v sortimentu dostupného keramického zboží, kdy tradiční domácí grafitovou keramiku nahradila charakteristická redukční keramika zpravidla již vytáčená na rychle rotujícím kruhu. Rozbory keramiky z přelomu 13. a 14. století však ukazují, že tato změna nebyla náhlá a grafitová keramika postupně mizela z českobudějovických městských domácností až v průběhu první poloviny 14. století. Stranou zůstává otázka, do jaké míry měla podíl na rychlém „zdomácněni““ redukční keramiky přítomnost německých komunit ve městě (srov. Kovář 2015, 111-114).

$\mathrm{Na}$ vyšší sociálně-ekonomický status by ukazovala přítomnost cizorodého keramického zboží a především doklady luxusní importované keramiky. V souboru středověké keramiky byly rozpoznány ojedinělé nálezy drobných keramických tvarů z tzv. bílého zboží, jehož původ lze zřejmě hledat západně od Čech. Př́itomnost zlomků světlé oxidační hrnčiny, červeně malovaného zboží nebo pozdně středověkých loštických pohárů je spíše dokladem obchodu a zásobování keramikou v regionálních a nadregionálních tržních vztazích, které jen obecně vypovídají o širších kontaktech (srov. Klápště 1997, 166). Importovaná keramika však netvoří ani procento z celkového počtu českobudějovické keramiky.

O vyšším standardu bydlení mohou svědčit nálezy kachlů. V souboru kamnářské keramiky převažovaly starší typy režných nádobkových kachlů, které je možné datovat již do průběhu 14. století. Naopak výrazně méně byly zastoupeny komorové kachle s čelní vyhřívací stěnou. Nádobkové kachle v kamnovém tělese mohly mít mnohem delší životnost až do průběhu 15. století, ale jejich nálezy pocházejí ze zadních dvorních traktů domů.

Zajímavý a početně reprezentativní je soubor středověkého dutého skla, v němž dominují především číše českého typu. Nálezy skel, datované nezávisle, ale i podle keramiky, jsou dokladem užití skleněných nádob v měšt’anských domácnostech již od přelomu 13. a 14. či počátku 14. století. Velký počet nálezů skel jako stolního picího nádobí, zejména číší českého typu může být i př́ičinou toho, proč v souborech vrcholně a pozdně středověké keramiky výrazně chybí nálezy stolních keramických nádob - pohárů a menších džbánků. Tento předpoklad je třeba ověřit i jinde, ovšem jisté je, že poháry jsou celkově v Českých Budějovicích zastoupeny výrazně méně oproti jiným městům v Čechách. Je třeba poukázat na to, že soubor skel z městské radnice je dosud nejpočetnějším a nejreprezentativnějším souborem středověkých až raně novověkých skel z historického jádra města (srov. Militký 1995, 84), ale chybí podrobné vyhodnocení dalších nálezů skel.

Poznání dokladů „profesních“ aktivit na městských parcelách je velmi omezené, přitom České Budějovice byly městem výrazného řemeslnického charakteru - na přelomu 14. a 15. století se až 61 \% obyvatel věnovalo řemeslům (Borská-Urbánková 1964, 169). Většina z nalezeného fondu železných a kovových předmětů náleží do kategorie stavebního kování či provozního vybavení, pouze ojediněle byly nalezené předměty zařazeny do skupin řemeslnických či zemědělských nástrojů. V knize městských dávek, tzv. knize lozunků z roku 1398 je ve vnitřním městě uveden podle ocenění nemovitostí pouze jeden kovář - měštan vlastnící dům - a pět kovářských podruhů. Podle označení (fabri, smide) však vystupuje v knize lozunků celkem až deset kovářù. Jejich počet se nezměnil ani v knize lozunků z roku 1416, v době, kdy výrazně vzrostl počet obyvatel města (Borská-Urbánková 1964, 140, 144, 158; k interpretaci berní knihy srov. Čechura 1987). Kovářská řemeslná činnost se mohla soustřed’ovat i na předměstích (srov. Krajíc 2003). Nepočetný soubor předmětů ze železa může také svědčit o hospodárném zacházení s kovy, které i po mechanickém znehodnocení zůstávaly nadále cennou surovinou (viz Nováček 2000, 30; Klápště ed. 2002, 125; srov. Buśko-Piekalski 1998, 26). Ve vnitřním městě se dále nacházela především velká diferenciace drobných řemeslníků zacházejících s barevnými a železnými kovy zlatníci, cínaři, konváři, číšiři, nožíři, mečíři, ostružníci, platnéři, zámečníci a pasíři (Borská-Urbánková 1964, 140, 144, 158), kteří mohli produkovat drobný výrobní odpad. Zajímavý je především soubor předmětů v kategorii barevných kovů, které většinou lze označit za tzv. ztrátové předměty. Rozborem sociální topografie města byla zjištěna pasiřská dílna, která se v 16. století 
nacházela v domě za radnicí, v České ulici (Kubák 1973, 174), odkud lze tedy vysvětlit př́tomnost předmětů z barevných kovů spadajících do kategorie osobní výbavy a součástí oděvu.

Nálezy slitků barevných kovů a střepů s natavenými kovovými krustami společně s nálezy několika keramických tyglíků ukazují na jisté doklady tavby barevných kovů, kterou lze považovat za jednu z mála archeologicky doložených činností. S těmito nálezy souvisí i dva zjištěné relikty kruhových „metalurgických“ pícek v přední části parcely B v interiéru gotického traktu domu. Na základě zjištění těchto aktivit lze připustit drobnou výrobní činnost na dvoře městských parcel.

Vyjma masného krámu a obchodu se solí není zaznamenána další řemeslnická a obchodní činnost př́ímo provozovaná majiteli či obyvateli městských domů. Nízký počet zemědělských nástrojů je rovněž dokladem, že zemědělská činnost se odehrávala v zázemí, ve vsích přidružených k městu, kde měštané vlastnili usedlost (dvůr) zaměřený na agrární produkci. Ke konstatování výlučnosti materiální kultury z nádvoří městské radnice v kontextu stř̌edověkých a novověkých Českých Budějovic nám chybí podrobné zpracování artefaktů z jiných částí města, abychom je mohli konfrontovat s výpovědní hodnotou celého nálezového souboru z nádvoří městské radnice.

Studie je výstupem grantového projektu SGS-2014-39: Historická radnice v Českých Budějovicích ve světle archeologických výzkumů a rozboru hmotných pramenů.

\section{Prameny}

LIBER LOSUNGARUM ab ao 1492: Kniha lozunků z roku 1492, ulož. v SOkA České Budějovice, fond Archiv města České Budějovice, sign. f. 10.

LIBER LOSUNGARUM ab ao 1514: Kniha lozunků z roku 1514, ulož. v SOkA České Budějovice, fond Archiv města České Budějovice, sign. f. $9 \mathrm{v}, 10,10 \mathrm{v}$.

MILITKÝ, J., 2001: Zpráva o archeologickém výzkumu na lokalitě: České Budějovice, náměstí Přemysla Otakara II. čp. 1-2 (areál historické radnice - sezóny 1996-1997). Archiv JČM České Budějovice. České Budějovice.

MUK, J.-URBAN, J.-VLČEK, P., 1988: České Budějovice radnice (čp. 1 a 2) - stavebně historický průzkum. Praha. Rukopis uložen v archivu Národního památkového ústavu - územní odborné pracoviště v Českých Budějovicích.

\section{Literatura}

BAUMGARTNER, E.-KRUEGER, I., 1988: Phoenix aus Sand und Asche. Glas des Mittelalters. München. BELCREDI, L., 1989: Terminologie, třídění a kód středověkých kovových předmětů - Terminologie, Klassifizierung und Kode mittelalterlicher metallischer Gegenstände, AH 14, 437-472.

- 2006: Bystřec. O založení, životě a zániku středověké vsi. Archeologický výzkum zaniklé stř̌edověké vsi Bystřece 1975-2005. Brno.

BORSKÁ-URBÁNKOVÁ, M., 1964: Majetková a sociální struktura Č. Budějovic koncem 14. a počátkem 15. stol., Sborník archivních prací 14, 119-178.

- 1965: Českobudějovické náměstí koncem 14. a začátkem 15. století, JSH 34, 116-127.

BUŚKO, C.-PIEKALSKI, J., 1998: Możliwości poznawcze archeologii w badaniach życie codziennego w średniowiecznym mieście, na przykłazie parcel przy ul. Więziennej 10-11 we Wrocławiu, Archeologia Historica Polona 7, 11-32.

CASTELIN, C. O., 1932: Př́śspěvky k chronologii haléřů Vladislavových a Ludvíkových (nález mělnický), Numismatický časopis československý 8, 63-73.

ČAPEK, L., 2013: Archeologické transformace v městském prostředí. Nepublikovaná disertační práce na Katedře archeologie Filozofické fakulty Západočeské univerzity v Plzni.

- 2015: Hrnčířské značky a kolky na středověké keramice z městské radnice a domu čp. 16 v Českých Budějovicích, AVJČ 28, 201-225.

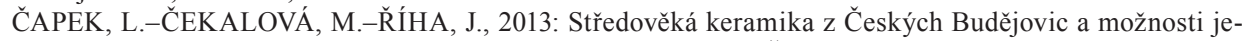
jího archeometrického studia - Mittelalterliche Keramik aus České Budějovice und die Möglichkeiten ihrer archäometrischen Untersuchung, AH 38, 525-542. 
ČECHURA, J., 1984: Počátky královského města České Budějovice, JSH 53, 57-68.

- 1987: Nová interpretace berní knihy Českých Budějovic z let 1396-1416, JSH 56, 1-11.

ČECHURA, J.-RAZÍM, V., 1988: K některým aspektům vývoje půdorysu a opevnění Českých Budějovic do počátku 15. století, Památky a příroda 13, 407-415.

ČERNÁ, E., 1995: Nálezy skel ze střredověkého Mostu - Mittelalterliche Gläser aus Most. In: Archeologické výzkumy v severozápadních Čechách v letech 1983-1992 (Blažek, J.-Meduna, P., edd.), 239-262. Most.

- 1996: Böhmisches mittelalterliches Glas und seine Darstellung in Bilderhandschriften und in der bildenden Kunst. In: Realienforschung und historische Quellen, Archäologische Mitteilungen aus Nordwestdeutschland, Beiheft 15, 157-136. Oldenburg.

- 2002: Sklo 13. až 16. století. In: Archeologie středověkého domu v Mostě (čp. 226). Mediaevalia archaeologica 4 (Klápště, J., ed.), 93-115. Praha - Most.

ČERNÁ, E. a kol., 1994: Středověké sklo v zemích Koruny české (katalog výstavy). Most.

ČURNÝ, M.-ŠIMČÍK, P.-BIELICH, M., 2013: Nálezy keramických fajok z archeologických výskumov a prospekcií na Slovensku I, ŠZ AÚ SAV 53, 85-101.

DESACHY, B., 2004: Sériographe 0.3 sous Excel: mode d'emploi.

DRAHOTOVÁ, O. a kol., 2005: Historie sklářské výroby v českých zemích. I. díl. Od počátků do konce 19. století. Praha.

ERNÉE, M.-VAŘEKA, P., 1998: Die Graphittonkeramik des 13. Jahrhunderts in Südböhmen und Prag, In: Frümittelalterliche Graphittonkeramik in Mitteleuropa. IV. Internationale Tagungen in Mikulčice (Poláček, L., ed.), 217-230. Brno.

ERNÉE, M.-VAŘEKA, P.-ZAVŘEL, P., 1997: Nové doklady osídlení 13. století na Českokrumlovsku - New Archaeological Evidence of the 13th Century Settlement in the Český Krumlov Region, AVJČ 14, $259-268$.

FRÝDA, F., 1988: Skleněné číše tzv. českého typu a jejich postavení v hmotné kultuře středověkých Čech. In: Sborník Kruhu přátel muzea hl. m. Prahy 1, 175-187. Praha.

- 1990: Typologie středověkého skla v Čechách od 13. do konce 15. století, Sborník západočeského muzea Historie 5, 59-84.

- 2007: Nálezy renesančního skla z Plzně, Historické sklo 4, 35-65.

GELNAR, M., 2014: Sklo. In: Hůrková, J. a kol., Archeologický výzkum panského sídla v Chanovicích, 319-339. Klatovy - Chanovice.

HÁNA, J., 2005: Haléře „Rotlevovy“ a „Kaplírovy“. Příspěvek k chronologii české drobné mince z let 1346-1384, Numismatický sborník 20, 109-126.

HARDER, J., 2010: Segmentgürtel mit mehrteiliger Anhängekombination - Ein Frauenschmuckgürtel der Renaissance, Historische Archäologie 3, 1-20.

HAZLBAUER, Z.-RICHTER, M., 1990: Dva hromadné nálezy gotických nádobkových kachlů v Sezimově Ústí, AR XLII, 416-434, 462-472.

HEEGE, A., 2009: Steinzeug in der Schweiz (14.-20. Jh.). Ein Überblick über die Funde im Kanton Bern und den Stand der Forschung zu deutschem, französischem und englischem Steinzeug in der Schweiz. Bern.

HEJDOVÁ, D.-NECHVÁTAL, B., 1967: Studie o středověkém skle v Čechách (Soubor z Plzně, Solní ulice), PA 58, 433- 498 .

HUYER, R., 1920: Das Budweiser Rathaus, Budweiser Zeitung 59, č. 84, 1- 3; č. 85, $1-3$.

JANKOVSKÁ, V. a kol., 2002: Jankovská, V.-Kočár, P.-Militký, J.-Pokorný, P.-Zavřel, P., Archaeobotany of the High Medieval town of České Budějovice - Archeobotanika středověkého města České Budějovice, AR LIV, 813-836.

KELLNER, H. J., 1997: Die Münzgeschichte des Hochstifts Passau. Ein Katalog der Münzen und Medaillen. Süddeutsche Münzkataloge. Band 6. Stuttgart.

KIBIC, K., 1988: Historické radnice. Praha.

KLÁPŠTĚ, J., 1997: Proměny keramiky ve středověkém městě Mostě, Archaeologia Historica Polona 5, $163-174$.

KLÁPŠTĚ, J., ed., 2002: Archeologie středověkého domu v Mostě (čp. 226). Mediaevalia archaeologica 4. Praha - Most.

KOVÁŘ, D., 2015: Fundatio civitatis. Zrození královského města Českých Budějovic. České Budějovice.

KRABATH, S., 2001: Die hoch- und spätmittelalterlichen Buntmetallfunde nördlich der Alpen. Eine archäologisch-kunsthistorische Untersuchung. 2 Bände. Internationale Archäologie 6. Rahden/Westf.

KRAJÍC, R., 1990: Výzkum středověké studny v Soběslavi, okr. Tábor (II. Analýza souboru kuchyňské a stolní keramiky) - Die Erforschung eines mittelalterlichen Brunnens in Soběslav, Bez. Tábor. 2, Analyse des Ensembles von Küchen- und Tafelkeramik, AVJČ 7, 97-120.

- 1997: Středověká kachlová kamna v Táboře (Archeologický výzkum v Křižíkově ulici čp. 28). Tábor.

- 2003: Sezimovo Ústí. Archeologie středověkého poddanského města 3. Kovárna v Sezimově Ústí a analýza výrobků ze železa I-II. Praha - Sezimovo Ústí - Tábor.

- 2005: Středověké kamnářství. Výzdobné motivy na gotických kachlích z Táborska. Tábor. 
- 2014: Kovy. In: Hůrková, J. a kol., Archeologický výzkum panského sídla v Chanovicích, 345-390. Klatovy - Chanovice.

KRAJÍC, R., a kol. 1998: Dům pasíře Prokopa v Táboře - Archeologický výzkum odpadní jímky v domě čp. 220. Písek.

KUBÁK, J., 1973: Topografie města Českých Budějovic 1540-1800. České Budějovice.

LÍBAL, D.-MUK, J., 1969: Domy a opevnění v Českých Budějovicích v gotice a renesanci. In: Minulost a současnost Českých Budějovic, 57-74. České Budějovice.

LUNGERHAUSEN, A., 2004: Buntmetallfunde und Handwerksrelikte des Mittelalters und der frühen Neuzeit aus Archäologischen Untersuchungen in Braunschweig. In: Materialhefte zur Ur- und Frühgeschichte Niedersachsens. Rahden/Westf.

MAREŠ, F., 1920: Kronika budějovská, Věstník královské společnosti nauk, část II., 1-94.

MĚCHUROVÁ, Z., 2008: Jak se pracovalo na poli. Srovnání zemědělského nářadí ze zaniklých středověkých vsí s etnografickými sbírkami - Wie auf dem Feld gearbeitet wurde. Ein Vergleich zwischen den Ackerbaugeräten aus mittelalterlichen Ortswüstungen und ethnographischen Sammlungen, AH 33, 129-144.

- 2009: Drobná středověká plastika koníčka na Moravě - Mittelalterliche Kleinplastiken von Pferdchen in Mähren. Überlegungen und Beobachtungen, AH 34, 173-189.

- 2012: Pásové řetězy ze sbírek Moravského zemského muzea v Brně jako archeologický doklad renesančního a užitého umění - Bandketten aus den Sammlungen des Mährischen Landesmuseums in Brno als archäologischer Beleg für die angewandte Kunst der Renaissance, AH 37, 747-766.

MILITKÝ, J., 1995: Archeologické výzkumy v Českých Budějovicích, Výběr 32, 77-85.

- 2014: Lhota nad Rohanovem (okr. Prachatice). In: Chvojka, O.-Krajíc, R. a kol., Poklady, depoty, obětiny... Jihočeské depoty od doby bronzové do novověku, 41-43. České Budějovice.

MUSIL, J., 2011: Raně novověké kovové článkové ženské opasky (tzv. Brautgürtel), Východočeský sborník historický 20, 21-52.

- 2012: Nález ženského kovového článkového opasku (tzv. Brautgürtel) z Podlažic, Chrudimský vlastivědný sborník 16, 87-138.

NEKUDA, V., 1985: Mstěnice. Zaniklá středověká ves u Hrotovic 1. Hrádek - tvrz - dvůr - předsunutá opevnění. Brno.

NECHANICKÝ, Z.-ŠAFÁŘ, O., 1983: Kladské mincovnictví. Hradec Králové.

NOVÁČEK, K., 2000: Středověký dům v Plzni. Archeologický výzkum parcely v Sedláčkově ulici 1 (čp. 187), Sborník Západočeského muzea v Plzni - Historie 15, 5-66.

NOVÁČEK, K.-TETOUR, M., 2000: Možnosti využití databázových systémů pro zpracování keramického materiálu. Formalizovaná deskriptivní databáze KLASIKER. Nepublikovaný rukopis ulož. na Katedře archeologie FF ZČU v Plzni.

NOVÁČEK, K. a kol., 2014: Nováček, K.-Stočes, J.-Široký, R.-Malivánková-Wasková, M., Počátky Nové Plzně a její vývoj do husitství. In: Dějiny města Plzně I. Do roku 1788, 123-186. Plzeň.

ORNA, J., 2005: Gotické a renesanční kachle ve sbírkách Západočeského muzea v Plzni. Plzeň.

PAJER, J., 1983: Počátky novověké keramiky ve Strážnici. Strážnice.

PREUSZ, M., 2015: Keramika 16. a první poloviny 17. století v Praze a jihozápadních Čechách. Inovace a kontinuita hrnčířské produkce. Nepublikovaná disertační práce na Katedře archeologie Západočeské univerzity v Plzni.

- 2015a: Novověké dýmky z Českých Budějovic, AVJČ 28, 309-337.

PREUSZ, M. a kol., 2014: Preusz, M.-Beneš, J.-Kovačiková, L.-Kočár, P.-Kaštovský, J., What Did They Eat, What Did They Drink, and from What? An Interdisciplinary Window into Everyday Life of the Early Modern Burgher's Household in Český Krumlov (Czech Republic), IANSA V/1, 59-77.

PROCHÁZKA, R., 1990: Kovové předměty z výbavy středověkého měšt’ana z výzkumu v Brně - Pekařské ulici - Metallgegenstände der Ausstattung des mittelalterlichen Bürgers aus der Ausgrabung in Brno Pekařská ulice, AH 15, 99-107.

PROCHÁZKA, R.-PEŠKA, M., 2007: Deskripční systém brněnské keramiky. Př́iloha 1, PV 48, $234-270$.

PROKOPOVÁ, K., 2014: Forschungstand zum mittelalterlichen Glas in Prag. In: Glasarchäologie in Europe. Regionen - Produkte - Analysen. Beiträge zum 5. Internationalen Symposium zur Erforschung Mittelalterlichen und Frühneuzeitlicher Glasshütten Europas (Černá, E.-Steppuhn, P., edd.), $127-143$. Seiffen/Erzgebirge.

RICHTER, M.-KRAJÍC, R., 2001: Sezimovo Ústí. Archeologie středověkého poddanského města, 2. Levobřežní předměstí - archeologický výzkum 1962-1988. Archeologický ústav AV ČR. Praha. 
SEDLÁČKOVÁ, H., 2003: Typologie des Glases aus dem 13. und 14. Jahrhundert aus Brünn, Mähren. In: Auf gläsernen Spuren. Der Beitrag Mitteleuropas zur archäologisch-historischen Glasforschung. Beiträge zur Mittelalterarchäologie in Österreich 19, 127-138. Wien.

- 2004: Středověké sklo z Opavy - Mittelalterliches Glas aus Opava/Troppau, PA 95, 223-264.

SCHARRER-LIŠKA, G., 2007: Die hochmittelalterliche Grafitkeramik in Mitteleuropa und ihr Beitrag zur Wirtschaftgeschichte: Forschungsstand - Hypothesen - offene Fragen. Mainz.

SMETÁNKA, Z., 1969: K morfologii českých středověkých kachlů, PA 60, 228-262.

STADLER, H.-REITMAIER, T., 2003: Hohl-und Flachglasfunde aus mittelalterlichen Burgengrabungen in Tirol und Oberkärnten. In: Auf gläsernen Spuren. Der Beitrag Mitteleuropas zur archäologisch-historischen Glasforschung. Beiträge zur Mittelalterarchäologie in Österreich 19, 189-210. Wien.

TETOUR, M., 2014: Destrukce kachlových kamen pod podlahou jižního sklepa. In: Hůrková, J. a kol., Archeologický výzkum panského sídla v Chanovicích, 243-289. Klatovy - Chanovice.

TARCSAY, K., 2003: Zum Stand der mittelalterlichen und neuzeitlichen Glasforschung in Österreich. In: Auf gläsernen Spuren. Der Beitrag Mitteleuropas zur archäologisch-historischen Glasforschung. Beiträge zur Mittelalterarchäologie in Österreich 19, 165-178. Wien.

VAŘEKA, P., 1998: Proměny keramické produkce vrcholného a pozdního středověku v Čechách - The erratic character of ceramic production in the High and Later Middle Ages in Bohemia, AR L, 123-137.

VYŠOHLÍD, M., 2009: Keramické dýmky v archeologických nálezech a jejich vypovídací možnosti - Clay tobacco pipes in the archaeological finds and their ability to testify, ASČ 13, 965-1000.

WAGNER, E.-DROBNÁ, Z.-DURDÍK, J., 1956: Kroje, zbroj a zbraně doby předhusitské a husitské. Praha.

\section{Zusammenfassung}

\section{Mittelalterliche und neuzeitliche Artefakte aus dem Hof des Rathauses von České Budějo- vice und ihre sozialökonomische Aussage}

In den Jahren 1996-1997 wurde im Hof des Rathauses der Stadt České Budějovice eine großflächige archäologische Grabung durchgeführt, die durch die geplante Bebauung des Rathaushofes hervorgerufen wurde und in deren zeitlichem Vorlauf erfolgte. Während der archäologischen Grabung konnten drei bis vier Stadtparzellen freigelegt werden, die bereits existierten, bevor das renaissancezeitliche Rathaus im Jahr 1555 gebaut wurde. Durch die Grabung wurde eine Fülle von mittelalterlichen und neuzeitlichen Artefakten gewonnen, die dem Material nach in Gebrauchs- und Ofenkeramik, Glas, Eisen- und Metallgegenstände, Münzen und Gegenstände aus den organischen Materialien Holz und Leder unterteilt wurden. Ziel der vorliegenden Studie ist es, das Grundspektrum der materiellen Kultur städtischer Haushalte und Artefakte vorzustellen, die mit der Existenz des renaissance- und barockzeitlichen städtischen Rathauses zusammenhängen. Unter Bezugnahme auf die Besitzverhältnisse und den höheren Wert von Immobilien konzentriert sich die Studie auch auf die Möglichkeit, den Aussagewert der materiellen Kultur bezüglich der sozialen und wirtschaftlichen Stellung der Bewohner von Stadthäusern darzulegen.

Alle Kategorien der Artefakte wurden einer typologischen und morphologischen Analyse unterzogen. Dabei ist es gelungen, eine fast komplette Entwicklungssequenz der Keramikformen bezüglich der Keramiktechnologie (anhand einer Analyse der Keramikklassen) und den Gruppen und Typen hinsichtlich Ränder und Verzierungen aufzustellen. Die ältesten Keramikhorizonte nach der Stadtgründung, d.h. nach 1265, werden durch Grafitkeramik (Grafittonkeramik) repräsentiert, die um das Jahr 1300 nach und nach durch Reduktionskeramik ersetzt wird. Eine weitere Änderung in der Keramikproduktion stellt der Umbruch des Spätmittelalters zur frühen Neuzeit dar, als glasierte Oxidationskeramik auftritt. In den Funden war auch Ofenkeramik vertreten, wobei Gefäßkacheln gegenüber Blattkacheln überwogen, was daraufhindeutet, dass in Stadthäusern Kacheln bereits im 14. Jahrhundert Verwendung fanden und eine längere Lebensdauer hatten. Interessant war eine Gruppe neuzeitlicher zweiteiliger Pfeifen aus Keramik und dreiteiliger Pfeifen aus Porzellan, die vor allem darüber Zeugnis ablegen, dass die Rauchkultur im 19. Jahrhundert in das soziale Milieu des Stadtrathauses von České Budějovice gelangte. 
Auffällig waren auch die Funde mittelalterlicher und frühneuzeitlicher Hohl- und Flachgläser, die vor allem aus dem Fundkontext von Brunnen und Abwassergruben stammten. Am meisten vertreten waren Becher böhmischen Typs mit charakteristischen Aufschmelzungen. Identifiziert wurden auch Nuppenbecher, Krautstrünke, Fragmente eines Kutrolfs und einer gerippten Flasche. Die Glasfunde aus dem städtischen Rathaus stellen bislang den größten Fundkomplex mittelalterlichen und neuzeitlichen Glases dar, der im historischen Stadtkern entdeckt wurde. Der Komplex an gefundenen Eisengegenständen ist zahlenmäßig gering, enthielt aber fast alle Grundgruppen, die den Lebensstandard des Wohnens, die Haushaltsausstattung oder das wirtschaftliche Umfeld betreffen. Weniger vertreten waren Gegenstände der Kategorie Werkzeuge des Handwerks und landwirtschaftliche Geräte, was ein Beleg dafür ist, dass sich Handwerksproduktion und landwirtschaftliche Tätigkeit woanders, d.h. außerhalb des Umlandes der Parzellen abspielte. Das Fehlen einiger von ihnen lässt sich im Zusammenhang mit dem wirtschaftlichen Umgang mit Metall erklären, das nach einer mechanischen Entwertung auch weiterhin ein wertvoller Rohstoff blieb. Zahlreicher vertreten waren Gegenstände aus Buntmetall, bei denen es sich meist um kleine Kleidungsbestandteile wie etwa Aufnäher oder Klammern handelte. Einzigartig war der Fund von Gürtelschnallen und eines hufeisenförmigen Gliedes von einem sogenannten Brautgürtel. Die meisten Gegenstände fallen in die Kategorie „Verluste“, zu denen auch mehrere Münzen gezählt werden können, aus denen ein kleinerer Sammelfund Münzen herausragt, bei denen es sich um Heller von Ladislaus Jagiello (Vladislav II. von Böhmen und Ungarn) handelte und die in der Verfüllung eines Ziegelsteinobjektes gefunden wurden. Fragmente aus Blech und Buntmetallbarren deuten zusammen mit den Funden kleiner Schmelztiegel aus Keramik darauf hin, dass hier bestimmte Tätigkeiten ausgeübt wurden, die mit der Metallbearbeitung verbunden waren.

Die Zusammensetzung des Fundkomplexes der Artefakte spiegelt gut die übliche Ausstattung städtischer Haushalte wider und veranschaulicht diese als Ort des Konsums. Die komplette Bearbeitung des Fundbestands an mittelalterlichen und neuzeitlichen Artefakten stellt eine in sich geschlossene Sondierung der materiellen Kultur in den städtischen Haushalten von České Budějovice dar.

Die vorliegende Studie ist ein Ergebnis des Förderprojekts SGS-2014-39: Das historische Rathaus in České Budějovice im Lichte von archäologischen Grabungen und einer Analyse von materiellen Quellen.

Mgr. Ladislav Čapek, Ph.D., Katedra archeologie Filozofické fakulty Západočeské univerzity v Plzni, Sedláčkova 15, 30601 Plzeň, Česká republika, capekla.st@kar.zcu.cz

Mgr. et. Mgr. Michal Preusz, Katedra archeologie Filozofické fakulty Západočeské univerzity v Plzni, Sedláčkova 15, 30601 Plzeň, Česká republika,preusz.michal@gmail.com

PhDr. Jiří Militký, Ph.D., Národní muzeum, Historické muzeum, Numismatické oddělení, Vinohradská 1, 11000 Praha 1, Archeologický ústav AV ČR, Praha, v. v. i., Letenská 4, 11801 Praha 1, Česká republika, militky.jiri@seznam.cz 
